\title{
The ubiquitin-proteasome system: opportunities for therapeutic intervention in solid tumors
}

\section{Daniel E Johnson}

Division of Hematology/Oncology, Departments of Medicine, and Pharmacology and Chemical Biology, University of Pittsburgh and the University of Pittsburgh Cancer Institute, Room 2.18c, Hillman Cancer Center, 5117 Centre Avenue, Pittsburgh, Pennsylvania 15213, USA
Correspondence should be addressed to D E Johnson Email johnsond@pitt.edu

\begin{abstract}
The destruction of proteins via the ubiquitin-proteasome system is a multi-step, complex process involving polyubiquitination of substrate proteins, followed by proteolytic degradation by the macromolecular 26S proteasome complex. Inhibitors of the proteasome promote the accumulation of proteins that are deleterious to cell survival, and represent promising anti-cancer agents. In multiple myeloma and mantle cell lymphoma, treatment with the first-generation proteasome inhibitor, bortezomib, or the second-generation inhibitor, carfilzomib, has demonstrated significant therapeutic benefit in humans. This has prompted United States Food and Drug Administration (US FDA) approval of these agents and development of additional second-generation compounds with improved properties. There is considerable interest in extending the benefits of proteasome inhibitors to the treatment of solid tumor malignancies. Herein, we review progress that has been made in the preclinical development and clinical evaluation of different proteasome inhibitors in solid tumors. In addition, we describe several novel approaches that are currently being pursued for the treatment of solid tumors, including drug combinatorial strategies incorporating proteasome inhibitors and the targeting of components of the ubiquitinproteasome system that are distinct from the 265 proteasome complex.
\end{abstract}
Key Words
- proteasome
- bortezomib
- carfilzomib
- oprozomib
- deubiquitinase
- solid tumor

Endocrine-Related Cancer (2015) 22, T1-T17

\section{Introduction}

The highly regulated degradation of cellular proteins is critically important for the ability of normal healthy cells to proliferate and differentiate (Ciechanover 2005). Similarly, induction of apoptosis in normal cells depends, in part, on selective protein degradation, leading to a decrease in the ratio of anti- vs pro-apoptotic proteins in the cell. The vast majority of protein degradation in the cell is accomplished via the ubiquitin-proteasome system, wherein proteins destined for degradation are covalently tagged with ubiquitin, and then subjected to proteolytic destruction by the macromolecular proteasome complex.
Cancer cells are commonly characterized by the overexpression or hyperactivation of proteins that promote aberrant progression through the cell cycle or suppression of apoptosis, or by the loss of proteins that are important for cell cycle checkpoints or the induction of apoptosis. A prevailing school of thought has suggested that inhibition of the proteasome may lead to the accumulation of proteins deleterious to the survival of cancer cells, allowing restoration of cell cycle arrest and/or apoptotic cell death. Indeed, numerous preclinical studies have now shown that inhibition of the proteasome results in

\footnotetext{
Published by Bioscientifica Ltd.

This paper forms part of a thematic review section on Ubiquitination and Cancer. The

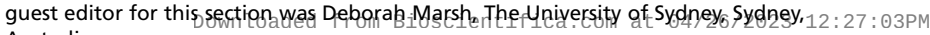
$\begin{aligned} \text { Australia } & \text { via free access }\end{aligned}$
} 
significant anti-cancer effects both in vitro and in vivo (Chen et al. 2011, Frankland-Searby \& Bhaumik 2012).

Bortezomib is a first-in-class reversible inhibitor of the proteasome that has achieved considerable success in the treatment of certain hematologic malignancies. Notably, the United States Food and Drug Administration (US FDA) has approved the use of bortezomib for multiple myeloma and mantle cell lymphoma (Kane et al. 2003, 2007, Richardson et al. 2003, 2005, Bross et al. 2004, Fisher et al. 2006). However, several factors limit both the shortand long-term success of bortezomib. Bortezomib exhibits considerable off-target effects that contribute to a high rate of peripheral neuropathy in treated patients (Richardson et al. 2006, Orlowski et al. 2007, Cavaletti \& Jakubowiak 2010, Corso et al. 2010). In addition, bortezomib is not orally bioavailable, and the reversible nature of this agent requires frequent intravenous delivery to maintain prolonged proteasome inhibition. Furthermore, many tumors exhibit inherent resistance to bortezomib, and most sensitive tumors eventually develop acquired resistance (Richardson et al. 2003, 2005, 2006, Lonial et al. 2005, O'Connor et al. 2005, Orlowski et al. 2007). In an effort to improve on the success of bortezomib and to overcome some of the limitations associated with this agent, considerable effort has been invested in the identification and development of next generation proteasome inhibitors, including MLN9708 (Kupperman et al. 2010, Chauhan et al. 2011), carfilzomib (Demo et al. 2007, Kuhn et al. 2007), oprozomib (Zhou et al. 2009, Chauhan et al. 2010), marizomib (NPI-0052 or salinosporamide A; Feling et al. 2003, Chauhan et al. 2005, Macherla et al. 2005), and delanzomib (CEP-18870; Dorsey et al. 2008, Piva et al. 2008). All of these inhibitors are currently undergoing clinical evaluation in hematologic and/or solid tumor malignancies.

Despite the major impact that bortezomib treatment has had on multiple myeloma and mantle cell lymphoma therapies, considerably less success has been seen in solid tumors. There are probably a number of factors that contribute to this paucity of success, but chief among them appears to be the inherent resistance of solid tumors in in vivo settings. It is hoped that second-generation proteasome inhibitors with different selectivities for proteasome subunits, enhanced or prolonged potencies, or reduced side effects will generate more satisfying effects on solid tumors. Moreover, it appears likely that the anti-cancer activities of proteasome inhibitors will be markedly improved through the development of rational drug combination strategies incorporating conventional or molecular targeting agents. Lastly, the ubiquitin-proteasome system is highly complex, involving regulatory and catalytic proteins beyond the central proteasome core. Efforts to target distinct components within this system are underway, and may provide a more efficacious way to convert highly proliferative or apoptosis-resistant solid tumor cells to a more vulnerable state. This review will focus on the basic steps and components of the ubiquitin-proteasome system, key proteins that are regulated by this system, the development and evaluation of small molecules targeting different system components, and the potential for combinatorial strategies against solid tumors.

\section{Protein degradation via the ubiquitin-proteasome system}

Proteins destined for degradation via the ubiquitinproteasome system include proteins that are damaged, improperly folded, or those that are intended to have short half-lives in the cell (Ciechanover 2005). Degradation of proteins by the ubiquitin-proteasome system is accomplished in two major steps: i) polyubiquitination of the protein and ii) proteolytic degradation of the polyubiquitinated protein by the macromolecular proteasome complex (Orlowski \& Wilk 2000, Ciechanover 2005, Shen et al. 2013). Each of these steps involves a complex series of protein interactions and biochemical events (Fig. 1).

Polyubiquitination of substrate proteins first involves activation of the 76-amino acid ubiquitin polypeptide by the activating enzyme E1. In humans, one primary E1 enzyme (Ube1) has been identified, although it remains possible that others may be found. Activation involves covalent linkage between the carboxyl-terminus of ubiquitin and a cysteine residue present on E1, forming a thioester bond. The activated ubiquitin is then transferred to an E2 ubiquitin-conjugating enzyme forming again a thioester covalent linkage. At least 50 distinct E2 enzymes have been identified in humans. In a third step, an E3 ligase enzyme transfers the ubiquitin from E2 to the substrate protein. As E3 proteins act to recognize and bind substrate proteins, it is not surprising that over 500 E3 enzymes appear to be encoded by the human genome. The majority of E3 ligases are classified as RING finger E3s, and act by bringing substrates and E2 enzymes into close proximity. The RING finger E3s then directly transfer ubiquitin from E2 to the substrate, without forming an intermediate covalent bond. A minority of E3 ligases (roughly 30) are classified as HECT domain E3s, and act by forming an intermediate thioester linkage with

Published by Bioscientifica Ltd. 


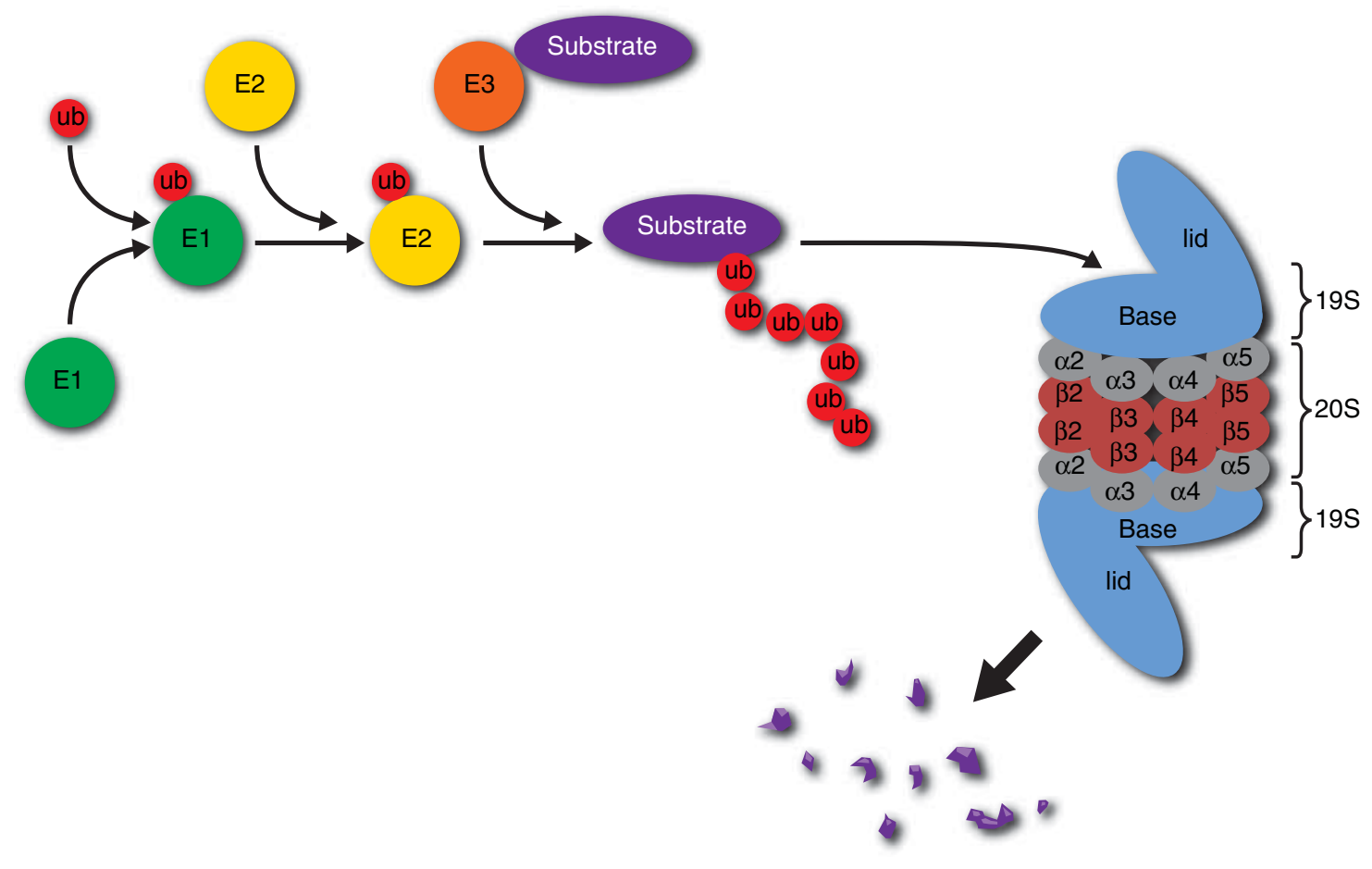

\section{Figure 1}

Degradation of proteins via the ubiquitin-proteasome system. The degradation of a substrate protein via the ubiquitin-proteasome system involves polyubiquitination of the protein, followed by proteasomal degradation. Ubiquitination involves the activation of ubiquitin by E1, intermediate conjugation to an E2 ubiquitin-conjugating enzyme, then transfer of the ubiquitin to the substrate by an E3 ubiquitin ligase enzyme. The process is then repeated to achieve polyubiquitination of the substrate

ubiquitin before transfer to the substrate. The E3 enzymes ligate ubiquitin to lysine residues present on the substrate protein. Following monoubiquitination of the substrate, the process must be repeated to form an elongated chain of ubiquitin residues. Proper recognition of ubiquitinated substrates by the proteasome complex is thought to require a minimum of four ubiquitin residues in the polyubiquitin chain.

Proteins that have been appropriately polyubiquitinated are recognized and degraded by the $26 \mathrm{~S}$ macromolecular proteasome complex (Gallastegui \& Groll 2010). The $26 \mathrm{~S}$ complex consists of a $20 \mathrm{~S}$ catalytic core particle that is capped at both ends by $19 \mathrm{~S}$ regulatory particles. The $19 \mathrm{~S}$ regulatory particle can be further subdivided into lid and base components. Following recruitment to the proteasome, polyubiquitinated proteins undergo deubiquitination and unfolding (Fig. 2). The removal of ubiquitin is accomplished by a family of deubiquitinase (Dub) enzymes, some of which are associated with the $19 \mathrm{~S}$ lid. Ubiquitin polypeptides protein. The ubiquitinated substrate protein is then recognized for degradation by the 265 proteasome complex comprising two 195 regulatory particles and a $20 \mathrm{~S}$ catalytic core particle. The caspase-like (C-L), trypsin-like (T-L), and chymotrypsin-like (CT-L) activities of the 205 particle are present in the $\beta 1, \beta 2$, and $\beta 5$ subunits respectively. Substrate proteins are degraded to oligopeptides.

that are removed from substrate proteins can be directly recycled by the cell. The $19 \mathrm{~S}$ base component plays a key role in unfolding of the substrate protein and delivery of the unfolded, deubiquitinated substrate into the $20 \mathrm{~S}$ catalytic core particle. The $20 \mathrm{~S}$ catalytic core particle consists of four layers of ring-like structures (Groll et al. 1997). The outer ring layers are composed of seven 'alpha' subunits, $\alpha 1-\alpha 7$, while the inner 'beta' rings are composed of seven beta subunits, $\beta 1-\beta 7$. The $\beta 1$ subunits exhibit caspase-like (C-L) proteolytic activity, the $\beta 2$ subunits exhibit trypsin-like (T-L) activity, and the $\beta 5$ subunits exhibit chymotrypsin-like (CT-L) activity. Collectively, these subunits act to degrade substrate proteins into short oligopeptides.

In addition to the widely distributed, constitutive proteasome complex described above, cells in the immune system express an inducible form of the proteasome called the immunoproteasome (Basler et al. 2013). The immunoproteasome differs in the composition of the beta subunits and the regulatory particle. Treatment with

Published by Bioscientifica Ltd. 

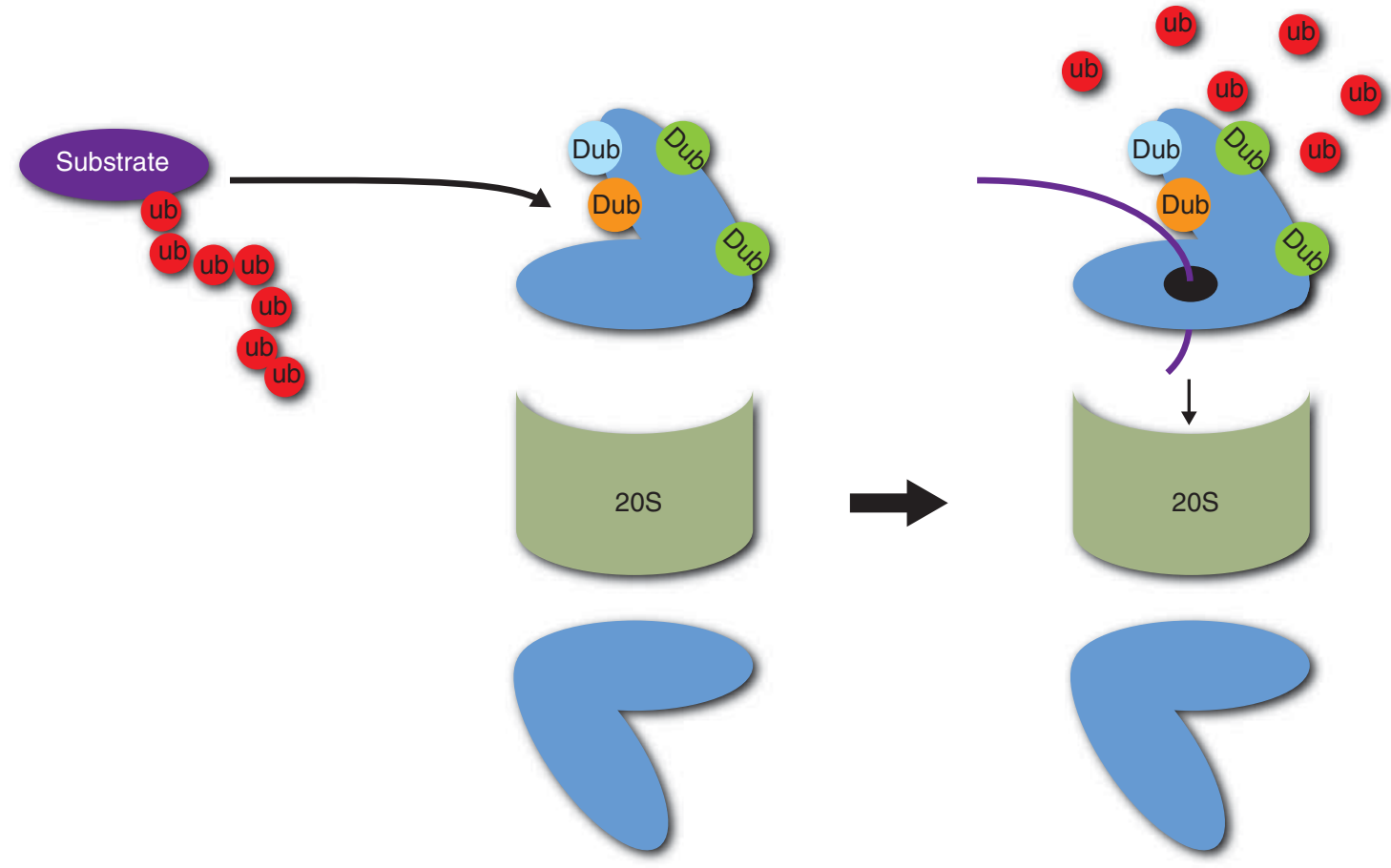

\section{Figure 2}

Substrate protein entry to the 20 S catalytic core. Before entry into, and degradation by, the $20 \mathrm{~S}$ catalytic core, polyubiquitinated proteins undergo deubiquitination by the members of the deubiquitinase (Dub) enzyme family. The released ubiquitin moieties are recycled by the cell.

interferon $\gamma$ or tumor necrosis factor $\alpha$ induces the expression of unique $\beta 1 \mathrm{i}$ (LMP2), $\beta 2 \mathrm{i}$ (MECL-1/LMP10), and $\beta 5 \mathrm{i}$ (LMP7) subunits that replace the $\beta 1, \beta 2$, and $\beta 5$ subunits of the constitutive proteasome. In addition, a unique $11 \mathrm{~S}$ regulatory particle is induced, which replaces the $19 \mathrm{~S}$ regulatory particle and caps the immunoproteasome complex. With elevated T-L and CT-L, and reduced $\mathrm{C}-\mathrm{L}$, activities, the immunoproteasome plays a key role in the generation of antigenic peptides that are used to generate MHC class I-mediated immune responses.

\section{Key proteins regulated by the ubiquitin-proteasome system}

\section{p53}

The tumor suppressor protein p53 acts as a transcription activator and plays key roles in the promotion of cell cycle arrest, as well as induction of apoptosis. Cellular levels of p53 are tightly regulated by the ubiquitin-proteasome system. HDM2, a RING finger E3 ligase, in complex with p300/CBP acts to promote polyubiquitination and rapid proteasomal degradation of the $\mathrm{p} 53$ protein. In view of the
The substrate protein also undergoes denaturation/unfolding. Entry of the substrate protein into the $20 \mathrm{~S}$ catalytic core particle is regulated by the base component of the $19 \mathrm{~S}$ regulatory particle.

capacity of p53 to promote either cell cycle arrest or apoptosis, inhibition of the interaction between p53 and HDM2, or inhibition of proteasome activity, as a means of elevating p53 levels in cancer cells has been intensively investigated (Brown et al. 2009). Of course, such a strategy requires that the cancer cells retain the capacity to express WT p53. However, the TP53 gene is among the most commonly mutated or deleted gene in human cancers, limiting the applicability of this approach.

A unique situation, and opportunity, exists in cancers characterized by infection with human papilloma virus (HPV). Nearly, all cases of cervical carcinoma and an increasing number of head and neck cancers harbor HPV (Shiboski et al. 2005, Chaturvedi et al. 2008, 2011, Nasman et al. 2009). In HPV-associated cancer, the viral E6 protein, in concert with the E6-associated protein, acts as a HECT domain E3 ligase, promoting the ubiquitination and proteasomal degradation of p53 (Scheffner et al. 1993). As p53 is efficiently removed via an HPV E6-mediated process, HPV-positive cancer cells have little selective pressure to mutate or delete the TP53 gene. Accordingly, nearly all cases of HPV-positive cervical carcinoma and head and neck cancer retain the ability to produce WT p53

Published by Bioscientifica Ltd. 
(Balz et al. 2003, Poeta et al. 2007, Westra et al. 2008). This suggests that treatment with E6 or proteasome inhibitors may be particularly useful for restoring the expression of WT p53 in HPV-positive solid tumors.

\section{p27}

The cyclin-dependent kinase (CDK) inhibitor p27 plays a key role in regulating the entry of quiescent cells into the cell cycle. Inhibition of the cell cycle by transforming growth factor $\beta$ or cell-cell contact is mediated, in part, by p27, and proteasomal degradation of p27 allows resumption of cell cycle progression. Ubiquitination of p27 occurs via a complex series of biochemical events, ultimately involving the RING finger E3 ligase complex $\mathrm{SCF}^{\text {Skp2 }}$ (Shen et al. 2013). Interestingly, activation of the E3 ligase activity of the $\mathrm{SCF}^{\mathrm{Skp} 2}$ complex requires the attachment of NEDD8, a polypeptide similar to ubiquitin, to a component of the protein complex (Merlet et al. 2009). As discussed later, this has spurred the development of neddylation inhibitors as a means of restoring p27 expression and cell cycle arrest in cancer cells.

\section{Cyclins}

Cyclins associate with CDKs to promote CDK activation and drive progression through the cell cycle. More than 15 different cyclins have been identified in humans, each acting at a particular phase of the cell cycle. Cyclins were named due to the fact that their expression levels vary, or cycle, dramatically throughout the cell cycle. Cyclin levels are tightly regulated by both transcriptional induction and proteasomal degradation. Inhibition of the proteasome, resulting in aberrant expression of cyclins throughout the cell cycle, has the potential to promote inappropriate CDK activation and cell cycle progression. In cancer cells, this may have a therapeutic benefit by activating safeguard apoptosis or mitotic catastrophe cell death mechanisms.

\section{NOXA, BAX, and BIK}

Multiple investigations have shown that inhibition of the proteasome leads to upregulation of pro-apoptotic members of the BCL2 protein family, including NOXA, BAX, and BIK (Qin et al. 2005, Zhu et al. 2005a,b, Fribley et al. 2006, Perez-Galan et al. 2007, Voortman et al. 2007a, Li et al. 2008). Moreover, the use of antisense oligonucleotides, siRNAs, or shRNAs, has shown that these family members are partially responsible for mediating cell death induction by proteasome inhibitors in cell line models representing melanoma (Qin et al. 2005), head and neck cancers (Fribley et al. 2006, Li et al. 2008), and colon cancer (Zhu et al. 2005a). NOXA and BAX are known to be induced by p53 (Miyashita \& Reed 1995, Oda et al. 2000), and their upregulation in response to proteasome inhibition may result from the elevation of p53 levels, although p53independent mechanisms of NOXA and BAX upregulation have also been described (Qin et al. 2005). The mechanisms responsible for the potent upregulation of BIK that has been reported in proteasome inhibitor-treated solid tumor cell lines are less well understood.

\section{MCL1}

In addition to causing upregulation of pro-apoptotic BCL2 family members, proteasome inhibitors have also been shown to dramatically increase the levels of MCL1, an anti-apoptotic BCL2 family member (Opferman 2006, Li et al. 2008, Zang et al. 2012a). Biochemical studies have shown that MCL1 is a direct proteasome substrate (Opferman 2006). Since MCL1 acts to inhibit apoptosis, co-treatment with a proteasome inhibitor and an inhibitor of MCL1 expression or function is likely to enhance the cell death-inducing activity of the proteasome inhibitor. Indeed, use of the MCL1 inhibitor, obatoclax (GX15-070) or shRNAs directed against MCL1 mRNA, has been shown to markedly improve the potencies of proteasome inhibitors against cancer cells of hematologic or solid tumor origin (Perez-Galan et al. 2007, 2008, Li et al. 2008, Zang et al. 2012a).

\section{TRAIL receptors}

The plasma membrane receptors, DR4 and DR5, bind and mediate the induction of the extrinsic apoptotic pathway by the death ligand TRAIL. Treatment of cells with proteasome inhibitors has been shown to upregulate the expression of DR4 and DR5, enhancing sensitivity to TRAIL (Nikrad et al. 2005, Liu et al. 2007, Voortman et al. 2007b, Shanker et al. 2008, Seki et al. 2010, Yoshiba et al. 2011). Although the mechanism of DR4 and DR5 upregulation is incompletely understood, preclinical studies suggest the potential therapeutic benefit of co-treatment with TRAIL and proteasome inhibitors in solid tumors.

\section{NF-кB}

The NF- $\mathrm{BB}$ transcription factor induces the expression of a wide variety of genes important for cellular proliferation

Published by Bioscientifica Ltd 
and survival, as well as inflammation and angiogenesis (Ghosh \& Karin 2002). Normally, NF-кB is maintained in an inactive state through sequestration in the cytoplasm by the endogenous inhibitor I $\kappa$ B (Ghosh \& Baltimore 1990). The activation of NF- $\kappa B$ by external stimuli involves phosphorylation of $\mathrm{I} \kappa \mathrm{B}$, leading to IкB ubiquitination and proteasomal degradation (Traenckner et al. 1995). The liberated NF- $\kappa \mathrm{B}$ migrates to the nucleus and therein promotes gene transcription. NF- $\kappa \mathrm{B}$ is also well known to be constitutively overexpressed and/or hyperactivated in a wide variety of hematologic and solid tumor malignancies (Aggarwal 2004, Van Waes 2007). Treatment with proteasome inhibitors is a well-established approach for suppressing I $\mathrm{K} B$ degradation and, thereby, inhibiting the cancer-promoting activity of constitutively activated NF-кB (Traenckner et al. 1994).

\section{Inhibitors of the proteasome 205 catalytic subunit}

\section{Bortezomib}

Bortezomib (Millenium-Takeda Oncology) is the first proteasome inhibitor to be approved by the US FDA for the treatment of cancer (Kane et al. 2003, 2007, Richardson et al. 2003, 2005, Bross et al. 2004, Fisher et al. 2006). Bortezomib is a dipeptidyl boronate compound that binds to the $\beta 5$ subunit in a reversible fashion, inhibiting the CT-L activity of the 20S catalytic core particle (Chen et al. 2011). However, bortezomib is not entirely specific, with modest inhibitory activity against the $\beta 1$ subunit, as well as inhibitory activities against a variety of serine proteases, including cathepsins A and $G$, chymase, dipeptidyl peptidase II, and HtrA2/Omi (Arastu-Kapur et al.). It has been proposed that these nonspecific activities contribute to the high rate of peripheral neuropathy that has been observed in bortezomib-treated patients (Arastu-Kapur et al.). Owing to the reversible nature of bortezomib, prolonged inhibition of the proteasome in vivo may require relatively frequent administration, although this is somewhat mitigated by the slow rate of bortezomib dissociation from the $\beta 5$ subunit.

\section{MLN9708}

MLN9708 (Millennium-Takeda Oncology) is an orally bioavailable analog of bortezomib currently undergoing Phase I/II clinical evaluation in hematologic and solid tumor malignancies (Kupperman et al. 2010, Chauhan et al. 2011, Driscoll \& Woodle 2012). Like bortezomib,
MLN9708 is a peptide boronate compound. Following oral administration, the MLN9708 prodrug is metabolized to the active agent MLN2238, which acts as a reversible inhibitor of the $\beta 5$ subunit.

\section{Delanzomib}

Delanzomib (Cephalon), also called CEP-18770, is an orally bioavailable peptide boronate that inhibits the $\beta 5$ subunit (Dorsey et al. 2008, Piva et al. 2008). Preclinical studies have indicated that delanzomib and bortezomib exhibit similar activities against hematologic and solid tumors. However, delanzomib may demonstrate reduced adverse toxicities (Piva et al. 2008). Specifically, in comparison with bortezomib, delanzomib has shown significantly reduced cytotoxicity toward bone marrow stromal cells, bone marrow progenitor cells, and normal human intestinal epithelial cells. Currently, delanzomib is undergoing clinical evaluation in Phase I/II trials (clinicaltrials.gov).

\section{Carfilzomib}

Carfilzomib (previously called PR-171; ONYX Pharmaceuticals, Inc., South San Francisco, CA, USA) is a tetrapeptide epoxy-ketone that displays a high degree of selectivity for the $\beta 5$ subunit (Demo et al. 2007, Kuhn et al. 2007, O'Connor et al. 2009). The nonspecific activity of carfilzomib against other $\beta$ subunits and cellular serine proteases appears to be minimal (Arastu-Kapur et al. 2011), which may account for the substantially reduced rates of peripheral neuropathy that have been observed in carfilzomib-treated patients (Siegel et al. 2013). The epoxy-ketone moiety of carfilzomib forms an irreversible linkage with the $\beta 5$ subunit allowing prolonged inhibition of the CT-L activity of the proteasome. However, whether irreversible, vs reversible, proteasome inhibition provides a clear clinical benefit remains unresolved. Carfilzomib is not orally bioavailable and requires intravenous delivery. Recently, carfilzomib was approved by the US FDA for treatment of multiple myeloma patients who have previously been treated with bortezomib (Herndon et al. 2013). Clinical testing of carfilzomib has been advanced considerably and it is currently being evaluated in a range of clinical trials in both hematologic and solid tumor malignancies (clinicaltrials.gov). Solid tumors currently being evaluated in clinical trials of carfilzomib include small-cell lung cancer, non-small cell lung cancer (NSCLC), refractory renal cell cancer, and metastatic prostate cancer.

Published by Bioscientifica Ltd. 


\section{Oprozomib}

Oprozomib (previously called PR-047 and ONX-0912; ONYX Pharmaceuticals, Inc.) is an orally bioavailable analog of carfilzomib (Zhou et al. 2009, Chauhan et al. 2010). Like carfilzomib, oprozomib is an irreversible epoxy-ketone inhibitor with a high degree of specificity for the $\beta 5$ subunit. Early stage clinical testing of oprozomib in hematologic malignancies, primarily multiple myeloma, is ongoing. In addition, a Phase I trial of oprozomib in advanced stage solid tumors is also underway (clinicaltrials.gov).

\section{Marizomib}

Marizomib (Nereus Pharmaceuticals, San Diego, CA, USA), also called NPI-0052 or salinosporamide A, is a naturally occurring $\beta$-lactone compound that irreversibly inhibits the proteasome (Feling et al. 2003, Chauhan et al. 2005, Macherla et al. 2005). In contrast to the inhibitors described earlier, which primarily inhibit the $\beta 5$ subunit, marizomib inhibits $\beta 1, \beta 2$, and $\beta 5$. It is interesting that acquired resistance to bortezomib and carfilzomib in in vitro models frequently corresponds with overexpression or mutation of the $\beta 5$ subunit (Kale \& Moore 2012, Verbrugge et al. 2012), although this has not been observed in patients. Nonetheless, it has been proposed that the ability of marizomib to inhibit multiple proteasome activities ( $\beta 1, \beta 2$, and $\beta 5)$ may limit the development of acquired resistance in marizomib-treated patients. Marizomib is currently undergoing Phase I clinical testing in relapsed/refractory multiple myeloma, refractory lymphoma, and advanced solid tumor malignancies. In addition, marizomib in combination with vorinostat is being evaluated in a trial incorporating NSCLC, pancreatic cancer, melanoma, and lymphoma (clinicaltrials.gov).

\section{Proteasome inhibitors as monotherapy in the treatment of solid tumors}

Bortezomib is by far the most extensively evaluated proteasome inhibitor in clinical trials. A wealth of preclinical studies have shown that bortezomib exhibits anti-tumor activity against both hematologic and solid tumor malignancies (Chen \& Dou 2010). Among solid tumors, preclinical activity has been observed in the models of NSCLC (Liu et al. 2007, Voortman et al. $2007 a$ ), head and neck squamous cell carcinoma (HNSCC) (Sunwoo et al. 2001, Fribley et al. 2004, 2006, Li et al. 2008), hepatocellular carcinoma (Chen et al. 2009), melanoma (Qin et al. 2005), prostate cancer (Williams et al. 2003, Nikrad et al. 2005), colon cancer (Zhu et al. $2005 a, b)$, renal cell carcinoma (Bonner et al. 2010), and pancreatic cancer (Nawrocki et al. 2002). By contrast, clinical trials of bortezomib treatment (particularly as monotherapy) in solid tumors have generally produced less promising results. As discussed later, several emerging strategies offer hope for improving the efficacy of proteasome inhibitors in the clinic.

Clinical testing of bortezomib in solid tumors has been most extensive in aerodigestive tract tumors, particularly NSCLC and HNSCC. Notably, Phase II studies of bortezomib monotherapy by Li et al. (2010) and Besse et al. (2012) have failed to demonstrate clinical activity in patients with advanced stage NSCLC. It is possible, however, that specific subtypes of NSCLC may be more responsive to proteasome inhibitors. In a Phase II study, Ramalingam et al. (2011) observed modest clinical activity of bortezomib in patients with bronchioloalveolar carcinoma, a NSCLC subtype. In HNSCC, early phase clinical trials by Allen et al. (2008) and Gilbert et al. (2013) demonstrated pharmacodynamic effects (e.g. NF- $\kappa$ B inhibition) of bortezomib monotherapy, but improvement in clinical outcomes was not observed.

More limited clinical testing of bortezomib monotherapy has been performed in a variety of other solid tumor malignancies. These studies have demonstrated a lack of clinical benefit for monotherapeutic bortezomib in recurrent ovarian cancer (Aghajanian et al. 2009), unresectable hepatocellular carcinoma (Kim et al. 2012), and metastatic colorectal (Mackay et al. 2005), gastric (Shah et al. 2011), melanoma (Markovic et al. 2005), and prostate (Morris et al. 2007) cancers. Interestingly, in preclinical studies of triple-negative breast cancer, cell lines representing the basal-like subtype were found to be more sensitive to proteasome inhibitors than cell lines representing luminal and mesenchymal subtypes (Petrocca et al. 2013). This suggests that rigorous stratification of patients according to specific cancer subtypes may be necessary to reveal the therapeutic benefits of proteasome inhibitors in solid tumors.

Although the results of solid tumor clinical trials incorporating bortezomib monotherapy have been somewhat disappointing, several approaches are currently being pursued that may have a major positive impact on further application of proteasome inhibitors. First, as described earlier, a wave of second-generation proteasome inhibitors is currently being developed. As a first-generation inhibitor, the therapeutic efficacy of bortezomib is hindered by several factors, including

Published by Bioscientifica Ltd. 
nonspecificity and associated adverse toxicities, inherent and acquired resistance, and short-term reversible inhibition. Each of these factors is being addressed in secondgeneration proteasome inhibitors. For example, it is notable that reduced toxicities are seen with carfilzomib, oprozomib, and delanzomib, which may allow more frequent dosing and more potency in vivo. Moreover, agents like carfilzomib and oprozomib are effective in bortezomib-resistance multiple myeloma cell lines and primary multiple myeloma cells from patients refractory to bortezomib treatment (Kuhn et al. 2007, Chauhan et al. 2010). Second, mechanistic studies have determined that proteasome inhibitors also upregulate the expression of certain proteins (e.g. MCL1) that act to attenuate the killing activity of the agent. Co-targeting with inhibitors of these upregulated anti-apoptotic proteins, or other constitutively expressed pro-survival proteins, is likely to markedly increase the therapeutic efficacies of proteasome inhibitors. Third, as discussed later, molecular targeting of other protein components of the ubiquitin-proteasome system, either alone or in combination with inhibitors of the catalytic core, may be able to circumvent some of the inherent resistance mechanisms of solid tumors.

\section{Combinatorial strategies incorporating proteasome inhibitors}

\section{Proteasome inhibitors in combination with conventional chemotherapy or radiation}

Results from early-stage clinical testing indicate that bortezomib (and possibly next generation proteasome inhibitors) is unlikely to be effective as a monotherapy against solid tumors in humans. However, co-targeting strategies incorporating proteasome inhibitors with other selective or nonselective agents offer a promising opportunity for improving anti-tumor efficacies (Fig. 3). Numerous preclinical studies have demonstrated synergism between proteasome inhibitors and conventional chemotherapy drugs in both hematologic and solid tumor malignancies (Yang et al. 2009). Although combination of bortezomib with conventional chemotherapy in solid tumor clinical trials has yet to realize highly beneficial results, it should be noted that clinical trials in multiple myeloma have shown improvements in efficacy when bortezomib is combined with thalidomide, melphalan, dexamethasone, cyclophosphamide, arsenic trioxide, or doxorubicin (Berenson et al. 2007, Orlowski et al. 2007, Reece et al. 2008, Terpos et al. 2008, Popat et al. 2009, Chen et al. 2011). The evaluation of further drug combinations and administration schedules may be necessary to optimize potential synergy in solid tumors.

In NSCLC, Davies et al. (2009) have reported a notable survival benefit for bortezomib plus gemcitabine/ carboplatin in a Phase II trial of advanced disease, while a Phase II trial by Lara et al. (2011) demonstrated enhanced survival by sequential administration of docetaxel and bortezomib. In addition, clinical activity of bortezomib in combination with carboplatin/bevacizumab as first-line therapy was observed by Piperdi et al. (2012) in a Phase I/II trial of advanced NSCLC. However, Hoang et al. (2013) found only minimal anti-NSCLC activity when bortezomib was combined with vorinostat as a third-line therapy in a Phase II setting.

Bortezomib evaluation in HNSCC has incorporated patients with advanced stage, recurrent, and metastatic disease, and has focused on combination with radiation, conventional chemotherapy, or cetuximab. Pharmacodynamic modulation of NF- $\mathrm{KB}$ activity has been detected in patients receiving bortezomib in combination with radiation (Van Waes et al. 2005, Pugh et al. 2010). Moreover, Kubicek et al. (2012) have shown that the combination of bortezomib plus concurrent chemoradiotherapy (cisplatin) is well tolerated in previously treated and radiation-naïve patients. Phase II studies have shown that the addition of bortezomib to irinotecan or docetaxel provides only minimal therapeutic benefit (Chung et al. 2010, Gilbert et al. 2013). The addition of bortezomib to cetuximab-containing regimens has been evaluated in two Phase I trials. Dudek et al. (2009) combined bortezomib with cetuximab in a cohort of patients with solid tumors expressing epidermal growth factor receptors and found that the combination was modestly effective in promoting stable disease in both HNSCC and NSCLC. By contrast, Argiris et al. (2011) terminated a trial of bortezomib plus cetuximab and radiation when five of six patients underwent progression earlier than expected. Rather unexpectedly, these earlyprogressing patients were suspected to be HPV positive. Thus, the hoped-for utility of proteasome inhibitors in the treatment of HPV-positive cancers remains uncertain.

In Phase II studies of metastatic breast cancer, bortezomib in combination with pegylated liposomal doxorubicin or anti-hormone therapy failed to yield any objective clinical responses (Irvin et al. 2010). The additions of bortezomib to pegylated liposomal doxorubicin in platinum-resistant ovarian cancer and bortezomib to irinotecan in relapsed/refractory colorectal cancer have also failed to demonstrate any clinical benefit (Kozuch et al. 2008, Parma et al. 2012). Similarly, in a

Published by Bioscientifica Ltd. 


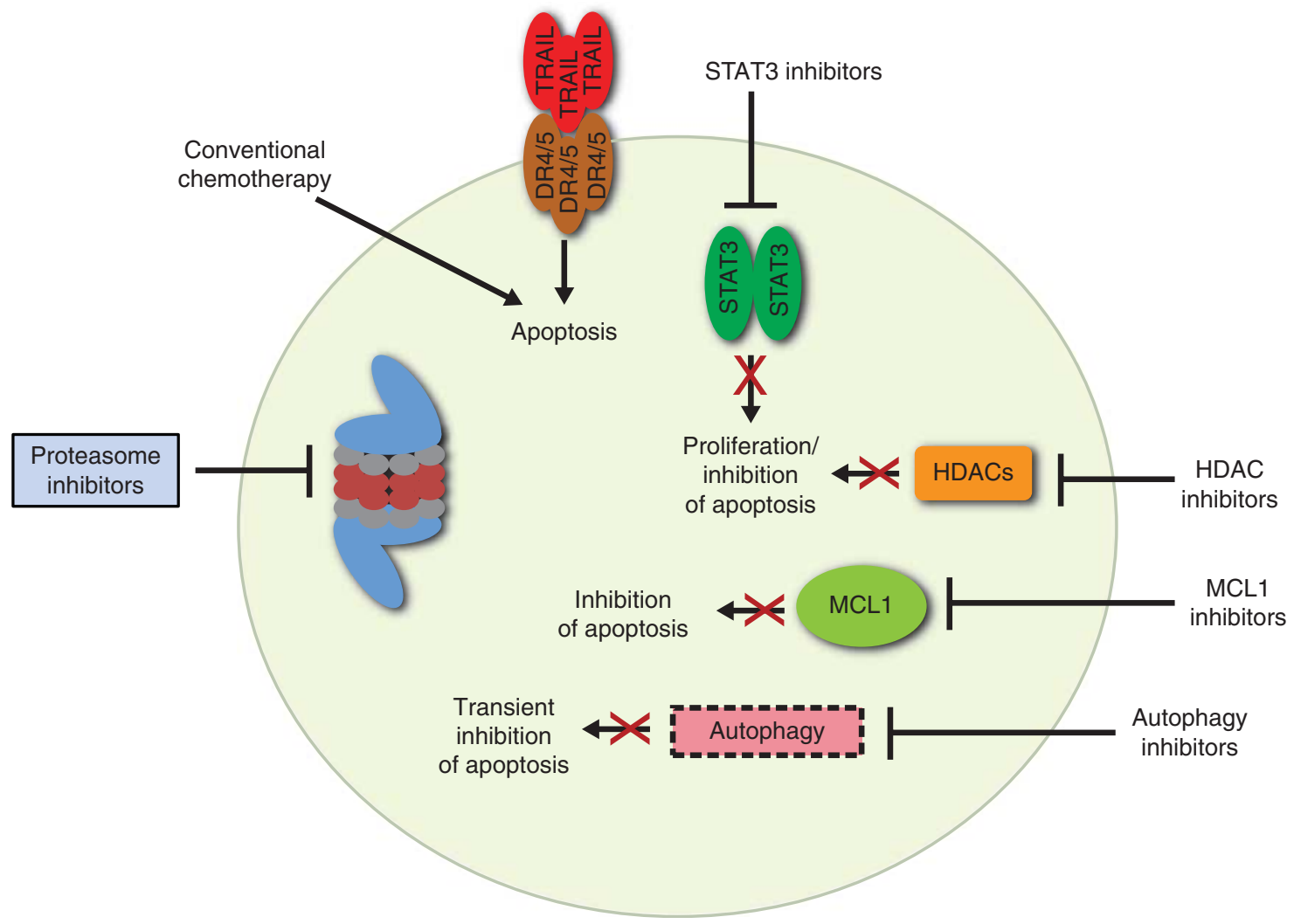

Figure 3

Co-targeting strategies for anti-cancer therapy. The figure depicts proteins or processes that can be targeted in combination with proteasome inhibitors to improve the efficacy of proteasome inhibitor therapy.

Phase II trial of metastatic prostate cancer, bortezomib in combination with prednisone did not exhibit significant anti-tumor effects (Morris et al. 2007). However, Kraft et al. (2011) have shown that bortezomib in combination with hormone deprivation therapy exerts a pharmacodynamic effect by changing the slope of prostate-specific antigen upregulation.

\section{Co-targeting the proteasome and cell surface death receptors}

Another opportunity for enhancing the anti-tumor efficacy of proteasome inhibitors may come from co-targeting DR4 and DR5, the cell surface receptors for the death ligand TRAIL (Fig. 3). Treatment of solid tumor cells with proteasome inhibitors has been shown to upregulate DR4 and DR5, enhancing cellular sensitivity to TRAIL (Nikrad et al. 2005, Liu et al. 2007, Voortman et al. 2007b, Shanker et al. 2008, Seki et al. 2010, Yoshiba et al. 2011). Targeting of DR4 and DR5 can be achieved through the use of recombinant TRAIL or agonistic antibodies to the receptors.

\section{Co-targeting the proteasome and MCL1}

In addition to inducing the expression of pro-apoptotic proteins that act to mediate cell killing, proteasome inhibitors also induce the expression or activation of proteins that promote cellular survival or proliferation (Fig. 3). Anti-apoptotic MCL1 is markedly upregulated in solid tumor cell lines treated with bortezomib, carfilzomib, or oprozomib (Opferman 2006, Li et al. 2008, Zang et al. 2012a). Suppression of MCL1 expression using siRNAs/shRNAs or inhibition of MCL1 function using obatoclax can result in synergistic induction of cell death (Perez-Galan et al. 2007, 2008, Li et al. 2008, Zang et al. $2012 a$ ). Thus, the combination of bortezomib with a highly selective MCL1 inhibitor represents a promising therapeutic approach.

\section{Co-targeting the proteasome and STAT3}

Bortezomib treatment has also been shown to induce the activation of STAT3 in HNSCC cells, and the inhibition of

Published by Bioscientifica Ltd 
STAT3 using a STAT3 decoy oligonucleotide or the naturally occuring compound guggulsterone results in enhanced cell killing following proteasome inhibition (Li et al. 2009). Clinical evaluation of proteasome inhibitors in combination with a STAT3 inhibitor awaits the development of a suitable clinical agent to inhibit STAT3.

\section{Co-targeting the proteasome and autophagy}

Proteasome inhibition also promotes the induction of autophagy in a variety of solid tumor cell lines (Ding et al. 2007, 2009, Zhu et al. 2009, Belloni et al. 2010, Li \& Johnson 2012). In most cases, the induced autophagy has been shown to temporarily enhance the survival of cells treated with proteasome inhibitors. Inhibition of autophagy using chloroquine can increase the sensitivity of solid tumor cells to bortezomib, carfilzomib, and oprozomib (Fig. 3; Hui et al. 2012, Zang et al. 2012b). Co-targeting of pro-survival autophagy and the proteasome in clinical trials of solid tumors seems warranted.

\section{Co-targeting the proteasome and epigenetic-modifying enzymes}

Finally, co-targeting with proteasome inhibitors and histone deacetylase (HDAC) inhibitors is currently being intensively investigated (Fig. 3). Yu et al. (2003) and Pei et al. (2004) were among the first to report potent synergy between proteasome and HDAC inhibitors in preclinical models of leukemia and multiple myeloma, respectively. Subsequently, preclinical synergy of these agents has been reported in a broad range of solid tumor cells, including cell line models representing ovarian (Bazzaro et al. 2008, Fang et al. 2011, Gatti et al. 2012), glioblastoma (Asklund et al. 2012), colon (Pitts et al. 2009), pancreatic (Bai et al. 2006, Spratlin et al. 2011), hepatocellular (Spratlin et al. 2011), HNSCC (Kim et al. 2010), and uterine (Lin et al. 2009) cancers. These studies have not been limited to the proteasome inhibitor bortezomib, as synergy of HDAC inhibitors with carfilzomib and marizomib has also been reported (Miller et al. 2007, Dasmahapatra et al. 2010, 2011). Clinical evaluation of combined treatment with proteasome inhibitors and HDAC inhibitors has been pursued most extensively in multiple myeloma (Hideshima et al. 2011). The VANTAGE 088 Phase III trial of multiple myeloma patients reported modestly prolonged progression-free survival (PFS) with vorinostat plus bortezomib (median $\mathrm{PFS}=7.63$ months) vs placebo plus bortezomib (median $\mathrm{PFS}=6.83$ months)
(Dimopoulos et al. 2013). The PANORAMA 2 Phase II trial of panobinostat plus bortezomib demonstrated restoration of clinical responses in bortezomib-refractory multiple myeloma (Richardson et al. 2013). The potential also exists for combination of proteasome inhibitors with other modulators of epigenetic mechanisms, such as demethylating agents. It is intriguing that bortezomib treatment has been shown to promote hypomethylation of genomic DNA (Liu et al. 2008). Moreover, the demethylating agent azacytidine reduces the expression of the multi-drug-resistance transporter MDR/P-gp, a major mediator of bortezomib resistance (Linenberger et al. 2001). Evaluation of proteasome inhibitors in combination with azacytidine or decitabine is warranted.

\section{Other promising targets in the ubiquitin-proteasome system}

As depicted in Figs 1 and 2, the degradation of proteins via the ubiquitin-proteasome system is a multi-step and complex process. Thus, opportunities for controlling the degradation of proteins in cancer therapies are not limited to targeting of the $20 \mathrm{~S}$ catalytic core particle. Numerous other protein and pathway nodes exist and are currently being investigated as sites for potential therapeutic intervention. Below, three brief examples of such efforts are described.

\section{Preventing p53 degradation}

In view of the ability of p53 to promote either cell cycle arrest or apoptosis, inhibition of p53 degradation in cancer cells is an attractive strategy. Ubiquitination of p53 is mediated by the E3 ligase HDM2. Over the past decade, considerable effort has been invested to identify small molecule inhibitors of HDM2 action or the interaction between HDM2 and p53. The nutlin compounds are the best characterized examples of this category of inhibitors (Vassilev et al. 2004, Vassilev 2007, Saha et al. 2013). Nutlins disrupt p53/HDM2 interactions, thereby inhibiting p53 ubiquitination. Nutlin treatment leads to p53 accumulation and induction of cell arrest and apoptosis. Importantly, nutlin induction of cell cycle arrest and/or apoptosis is restricted to cells that express wild-type p53, supporting the mechanism of action of these agents, but also highlighting a limitation of nutlins (and similar inhibitors) for broad use as anti-cancer drugs. More recently, a large number of novel HDM2 antagonists have been identified and are undergoing preclinical evaluation (Shen et al. 2013).

Published by Bioscientifica Ltd. 


\section{Inhibition of neddylation}

Restoration of the CDK inhibitor p27 in cancer cells has the potential benefit of inhibiting entry into the cell cycle, thereby slowing the growth of tumor cells. The p27 protein is subjected to ubiquitination and proteasomal degradation through the action of the $\mathrm{SCF}^{\mathrm{Skp} 2} \mathrm{E} 3$ ligase protein complex. Interestingly, activation of this complex requires conjugation with the ubiquitin-like polypeptide NEDD8 via a process termed neddylation (Merlet et al. 2009). Thus, inhibition of neddylation can be used to prevent $\mathrm{SCF}^{\text {Skp2 }}$ activation and p27 loss. Similar to the activation of ubiquitin by the E1 enzyme Ube1, nedd 8 is activated by the nedd8-activating enzyme (NAE; Soucy et al. 2010). Soucy et al. (2009) have identified a small molecule inhibitor of NAE called MLN4924. Treatment with MLN4924 promotes S-phase defects, apoptosis, and growth inhibition of solid tumor xenografts in mice (Soucy et al. 2009, Brownell et al. 2010, Milhollen et al. 2011). MLN4924 is currently undergoing early phase clinical testing.

\section{Inhibition of Dubs}

The degradation of proteins by the $20 \mathrm{~S}$ catalytic core is preceded by protein deubiquitination. Deubiquitination is accomplished by the Dub family of enzymes (Fig. 3). Roughly, 100 Dubs have been identified, with varying substrate specificities (Fraile et al. 2012). Thus, inhibition of selective Dubs may prove useful for altering the balance of pro- vs anti-apoptotic proteins in the cell. Chauhan et al. (2012) have identified the small molecule P5091 as an inhibitor of the Dub enzyme USP7. P501 induces apoptosis in bortezomib-refractory multiple myeloma cells and inhibits the growth of myeloma tumors in vivo (Chauhan et al. 2012). Recently, Tian et al. (2014) have shown that the compound b-AP15 acts to inhibit the deubiquitinating activity of USP14 and UCHL5, but does not impact overall proteasome activity. b-AP15 induces cell death in multiple myeloma cell lines and primary specimens and is able to overcome bortezomib resistance. Moreover, b-AP15 was shown to synergize with lenalidomide, dexamethasone, and vorinostat, and inhibit the growth of multiple myeloma xenograft tumors. Although early in preclinical development, additional inhibitors of Dub enzymes have also recently been identified (Shen et al. 2013).

\section{Future considerations}

The promise of proteasome inhibitors in the treatment of solid tumor malignancies has yet to be realized. At present, most clinical studies in solid tumors have been carried out using bortezomib the first-generation proteasome inhibitor. The second-generation compounds currently under development and evaluation offer the potential for improvements in potencies, selectivities, and other drug-like properties. Nonetheless, it seems likely that monotherapeutic application of proteasome inhibitors may have only limited success in solid tumors. It will be important to continue the development of co-treatment strategies that simultaneously target the proteasome and other proteins/pathways that suppress apoptosis or cell cycle arrest. Fortunately, there are numerous opportunities for co-targeting strategies, and multiple examples of synergistic anti-cancer drug combinations have been reported in preclinical solid tumor models. Whether such synergism will be demonstrated in human clinical trials warrants investigation. In addition, future studies should continue to be aimed at developing small molecule regulators of components of the ubiquitin-proteasome system that are distinct from the proteasome complex. The opportunities in this regard are tremendous, and are currently highlighted by efforts to develop inhibitors of the E1, E2, E3, and Dub enzymes. It is likely that targeting of these different enzymes may achieve either paninhibition or highly selective inhibition of protein degradation, with the therapeutic value of these endpoints yet to be determined.

\section{Declaration of interest}

The authors declare that there is no conflict of interest that could be perceived as prejudicing the impartiality of this review.

\section{Funding}

This work was supported by National Institutes of Health grant numbers R01 CA137260 and P50 CA097190.

\section{References}

Aggarwal BB 2004 Nuclear factor-кB: the enemy within. Cancer Cell 6 203-208. (doi:10.1016/j.ccr.2004.09.003)

Aghajanian C, Blessing JA, Darcy KM, Reid G, DeGeest K, Rubin SC, Mannel RS, Rotmensch J, Schilder RJ, Riordan W et al. 2009 A phase II evaluation of bortezomib in the treatment of recurrent platinumsensitive ovarian or primary peritoneal cancer: a Gynecologic Oncology Group study. Gynecologic Oncology 115 215-220. (doi:10.1016/j.ygyno. 2009.07.023)

Allen C, Saigal K, Nottingham L, Arun P, Chen Z \& Van Waes C 2008 Bortezomib-induced apoptosis with limited clinical response is accompanied by inhibition of canonical but not alternative nuclear factor- $\{\kappa\} B$ subunits in head and neck cancer. Clinical Cancer Research 14 4175-4185. (doi:10.1158/1078-0432.CCR-07-4470)

Published by Bioscientifica Ltd. 
Arastu-Kapur S, Anderl JL, Kraus M, Parlati F, Shenk KD, Lee SJ, Muchamuel T, Bennett MK, Driessen C, Ball AJ et al. 2011 Nonproteasomal targets of the proteasome inhibitors bortezomib and carfilzomib: a link to clinical adverse events. Clinical Cancer Research 17 2734-2743. (doi:10.1158/1078-0432.CCR-10-1950)

Argiris A, Duffy AG, Kummar S, Simone NL, Arai Y, Kim SW, Rudy SF, Kannabiran VR, Yang X, Jang M et al. 2011 Early tumor progression associated with enhanced EGFR signaling with bortezomib, cetuximab, and radiotherapy for head and neck cancer. Clinical Cancer Research 17 5755-5764. (doi:10.1158/1078-0432.CCR-11-0861)

Asklund T, Kvarnbrink S, Holmlund C, Wibom C, Bergenheim T, Henriksson R \& Hedman H 2012 Synergistic killing of glioblastoma stem-like cells by bortezomib and HDAC inhibitors. Anticancer Research 32 2407-2413.

Bai J, Demirjian A, Sui J, Marasco W \& Callery MP 2006 Histone deacetylase inhibitor trichostatin A and proteasome inhibitor PS-341 synergistically induce apoptosis in pancreatic cancer cells. Biochemical and Biophysical Research Communications 348 1245-1253. (doi:10.1016/ j.bbrc.2006.07.185)

Balz V, Scheckenbach K, Gotte K, Bockmuhl U, Petersen I \& Bier H 2003 Is the p53 inactivation frequency in squamous cell carcinomas of the head and neck underestimated? Analysis of p53 exons 2-11 and human papillomavirus 16/18 E6 transcripts in 123 unselected tumor specimens Cancer Research 63 1188-1191.

Basler M, Kirk CJ \& Groettrup M 2013 The immunoproteasome in antigen processing and other immunological functions. Current Opinion in Immunology 25 74-80. (doi:10.1016/j.coi.2012.11.004)

Bazzaro M, Lin Z, Santillan A, Lee MK, Wang MC, Chan KC, Bristow RE, Mazitschek R, Bradner J \& Roden RB 2008 Ubiquitin proteasome system stress underlies synergistic killing of ovarian cancer cells by bortezomib and a novel HDAC6 inhibitor. Clinical Cancer Research 14 7340-7347. (doi:10.1158/1078-0432.CCR-08-0642)

Belloni D, Veschini L, Foglieni C, Dell'Antonio G, Caligaris-Cappio F, Ferrarini M \& Ferrero E 2010 Bortezomib induces autophagic death in proliferating human endothelial cells. Experimental Cell Research 316 1010-1018. (doi:10.1016/j.yexcr.2009.11.005)

Berenson JR, Matous J, Swift RA, Mapes R, Morrison B \& Yeh HS 2007 A phase I/II study of arsenic trioxide/bortezomib/ascorbic acid combination therapy for the treatment of relapsed or refractory multiple myeloma. Clinical Cancer Research 13 1762-1768. (doi:10.1158/1078-0432.CCR-06-1812)

Besse B, Planchard D, Veillard AS, Taillade L, Khayat D, Ducourtieux M, Pignon JP, Lumbroso J, Lafontaine C, Mathiot C et al. 2012 Phase 2 study of frontline bortezomib in patients with advanced non-small cell lung cancer. Lung Cancer 76 78-83. (doi:10.1016/j.lungcan.2011. 09.006)

Bonner JA, Harari PM, Giralt J, Cohen RB, Jones CU, Sur RK, Raben D, Baselga J, Spencer SA, Zhu J et al. 2010 Radiotherapy plus cetuximab for locoregionally advanced head and neck cancer: 5-year survival data from a phase 3 randomised trial, and relation between cetuximabinduced rash and survival. Lancet Oncology 11 21-28. (doi:10.1016/ S1470-2045(09)70311-0)

Bross PF, Kane R, Farrell AT, Abraham S, Benson K, Brower ME, Bradley S, Gobburu JV, Goheer A, Lee SL et al. 2004 Approval summary for bortezomib for injection in the treatment of multiple myeloma. Clinical Cancer Research 10 3954-3964. (doi:10.1158/1078-0432.CCR-03-0781)

Brown CJ, Lain S, Verma CS, Fersht AR \& Lane DP 2009 Awakening guardian angels: drugging the p53 pathway. Nature Reviews. Cancer 9 862-873. (doi:10.1038/nrc2763)

Brownell JE, Sintchak MD, Gavin JM, Liao H, Bruzzese FJ, Bump NJ, Soucy TA, Milhollen MA, Yang X, Burkhardt AL et al. 2010 Substrateassisted inhibition of ubiquitin-like protein-activating enzymes: the NEDD8 E1 inhibitor MLN4924 forms a NEDD8-AMP mimetic in situ. Molecular Cell 37 102-111. (doi:10.1016/j.molcel.2009.12.024)

Cavaletti G \& Jakubowiak AJ 2010 Peripheral neuropathy during bortezomib treatment of multiple myeloma: a review of recent studies.
Leukemia \& Lymphoma 51 1178-1187. (doi:10.3109/10428194.2010. 483303)

Chaturvedi AK, Engels EA, Anderson WF \& Gillison ML 2008 Incidence trends for human papillomavirus-related and -unrelated oral squamous cell carcinomas in the United States. Journal of Clinical Oncology 26 612-619. (doi:10.1200/JCO.2007.14.1713)

Chaturvedi AK, Engels EA, Pfeiffer RM, Hernandez BY, Xiao W, Kim E, Jiang B, Goodman MT, Sibug-Saber M, Cozen W et al. 2011 Human papillomavirus and rising oropharyngeal cancer incidence in the United States. Journal of Clinical Oncology 29 4294-4301. (doi:10.1200/ JCO.2011.36.4596)

Chauhan D, Catley L, Li G, Podar K, Hideshima T, Velankar M, Mitsiades C, Mitsiades N, Yasui H, Letai A et al. 2005 A novel orally active proteasome inhibitor induces apoptosis in multiple myeloma cells with mechanisms distinct from Bortezomib. Cancer Cell 8 407-419. (doi:10.1016/j.ccr.2005.10.013)

Chauhan D, Singh AV, Aujay M, Kirk CJ, Bandi M, Ciccarelli B, Raje N, Richardson P \& Anderson KC 2010 A novel orally active proteasome inhibitor ONX 0912 triggers in vitro and in vivo cytotoxicity in multiple myeloma. Blood 116 4906-4915. (doi:10.1182/blood-2010-04276626)

Chauhan D, Tian Z, Zhou B, Kuhn D, Orlowski R, Raje N, Richardson P \& Anderson KC 2011 In vitro and in vivo selective antitumor activity of a novel orally bioavailable proteasome inhibitor MLN9708 against multiple myeloma cells. Clinical Cancer Research 17 5311-5321. (doi:10.1158/1078-0432.CCR-11-0476)

Chauhan D, Tian Z, Nicholson B, Kumar KG, Zhou B, Carrasco R, McDermott JL, Leach CA, Fulcinniti M, Kodrasov MP et al. 2012 A small molecule inhibitor of ubiquitin-specific protease-7 induces apoptosis in multiple myeloma cells and overcomes bortezomib resistance. Cancer Cell 22 345-358. (doi:10.1016/j.ccr. 2012.08.007)

Chen D \& Dou QP 2010 The ubiquitin-proteasome system as a prospective molecular target for cancer treatment and prevention. Current Protein \& Peptide Science 11 459-470. (doi:10.2174/ 138920310791824057)

Chen KF, Yeh PY, Hsu C, Hsu CH, Lu YS, Hsieh HP, Chen PJ \& Cheng AL 2009 Bortezomib overcomes tumor necrosis factor-related apoptosisinducing ligand resistance in hepatocellular carcinoma cells in part through the inhibition of the phosphatidylinositol 3-kinase/Akt pathway. Journal of Biological Chemistry 284 11121-11133. (doi:10.1074/jbc.M806268200)

Chen D, Frezza M, Schmitt S, Kanwar J \& Dou QP 2011 Bortezomib as the first proteasome inhibitor anticancer drug: current status and future perspectives. Current Cancer Drug Targets 11 239-253. (doi:10.2174/ 156800911794519752)

Chung CH, Aulino J, Muldowney NJ, Hatakeyama H, Baumann J, Burkey B, Netterville J, Sinard R, Yarbrough WG, Cmelak AJ et al. 2010 Nuclear factor- $\mathrm{\kappa B}$ pathway and response in a phase II trial of bortezomib and docetaxel in patients with recurrent and/or metastatic head and neck squamous cell carcinoma. Annals of Oncology 21 864-870. (doi:10.1093/ annonc/mdp390)

Ciechanover A 2005 Proteolysis: from the lysosome to ubiquitin and the proteasome. Nature Reviews. Molecular Cell Biology 6 79-87. (doi:10.1038/nrm1552)

Corso A, Mangiacavalli S, Varettoni M, Pascutto C, Zappasodi P \& Lazzarino M 2010 Bortezomib-induced peripheral neuropathy in multiple myeloma: a comparison between previously treated and untreated patients. Leukemia Research 34 471-474. (doi:10.1016/ j.leukres.2009.07.022)

Dasmahapatra G, Lembersky D, Kramer L, Fisher RI, Friedberg J, Dent P \& Grant S 2010 The pan-HDAC inhibitor vorinostat potentiates the activity of the proteasome inhibitor carfilzomib in human DLBCL cells in vitro and in vivo. Blood 115 4478-4487. (doi:10.1182/blood-200912-257261) http://erc.endocrinology-journals.org

DOI: 10.1530/ERC-14-0005
(C) 2015 Society for Endocrinology Printed in Great Britain 
Dasmahapatra G, Lembersky D, Son MP, Attkisson E, Dent P, Fisher RI, Friedberg JW \& Grant S 2011 Carfilzomib interacts synergistically with histone deacetylase inhibitors in mantle cell lymphoma cells in vitro and in vivo. Molecular Cancer Therapeutics 10 1686-1697. (doi:10.1158/ 1535-7163.MCT-10-1108)

Davies AM, Chansky K, Lara PN Jr, Gumerlock PH, Crowley J, Albain KS, Vogel SJ, Gandara DR \& Southwest Oncology G 2009 Bortezomib plus gemcitabine/carboplatin as first-line treatment of advanced non-small cell lung cancer: a phase II Southwest Oncology Group Study (S0339). Journal of Thoracic Oncology 4 87-92. (doi:10.1097/JTO. Ob013e3181915052)

Demo SD, Kirk CJ, Aujay MA, Buchholz TJ, Dajee M, Ho MN, Jiang J, Laidig GJ, Lewis ER, Parlati F et al. 2007 Antitumor activity of PR-171, a novel irreversible inhibitor of the proteasome. Cancer Research 67 6383-6391. (doi:10.1158/0008-5472.CAN-06-4086)

Dimopoulos M, Siegel DS, Lonial S, Qi J, Hajek R, Facon T, Rosinol L, Williams C, Blacklock H, Goldschmidt H et al. 2013 Vorinostat or placebo in combination with bortezomib in patients with multiple myeloma (VANTAGE 088): a multicentre, randomised, double-blind study. Lancet Oncology 14 1129-1140. (doi:10.1016/S14702045(13)70398-X)

Ding WX, Ni HM, Gao W, Yoshimori T, Stolz DB, Ron D \& Yin XM 2007 Linking of autophagy to ubiquitin-proteasome system is important for the regulation of endoplasmic reticulum stress and cell viability. American Journal of Pathology 171 513-524. (doi:10.2353/ajpath.2007. 070188)

Ding WX, Ni HM, Gao W, Chen X, Kang JH, Stolz DB, Liu J \& Yin XM 2009 Oncogenic transformation confers a selective susceptibility to the combined suppression of the proteasome and autophagy. Molecular Cancer Therapeutics 8 2036-2045. (doi:10.1158/1535-7163.MCT-081169)

Dorsey BD, Iqbal M, Chatterjee S, Menta E, Bernardini R, Bernareggi A, Cassara PG, D'Arasmo G, Ferretti E, De Munari S et al. 2008 Discovery of a potent, selective, and orally active proteasome inhibitor for the treatment of cancer. Journal of Medicinal Chemistry 51 1068-1072. (doi:10.1021/jm7010589)

Driscoll JJ \& Woodle ES 2012 Targeting the ubiquitin + proteasome system in solid tumors. Seminars in Hematology 49 277-283. (doi:10.1053/ j.seminhematol.2012.04.002)

Dudek AZ, Lesniewski-Kmak K, Shehadeh NJ, Pandey ON, Franklin M, Kratzke RA, Greeno EW \& Kumar P 2009 Phase I study of bortezomib and cetuximab in patients with solid tumours expressing epidermal growth factor receptor. British Journal of Cancer 100 1379-1384. (doi:10.1038/sj.bjc.6605043)

Fang Y, Hu Y, Wu P, Wang B, Tian Y, Xia X, Zhang Q, Chen T, Jiang X, Ma Q et al. 2011 Synergistic efficacy in human ovarian cancer cells by histone deacetylase inhibitor TSA and proteasome inhibitor PS-341. Cancer Investigation 29 247-252. (doi:10.3109/07357907.2010.496756)

Feling RH, Buchanan GO, Mincer TJ, Kauffman CA, Jensen PR \& Fenical W 2003 Salinosporamide A: a highly cytotoxic proteasome inhibitor from a novel microbial source, a marine bacterium of the new genus salinospora. Angewandte Chemie 42 355-357. (doi:10.1002/anie. 200390115)

Fisher RI, Bernstein SH, Kahl BS, Djulbegovic B, Robertson MJ, de Vos S, Epner E, Krishnan A, Leonard JP, Lonial S et al. 2006 Multicenter phase II study of bortezomib in patients with relapsed or refractory mantle cell lymphoma. Journal of Clinical Oncology 24 4867-4874. (doi:10.1200/JCO.2006.07.9665)

Fraile JM, Quesada V, Rodriguez D, Freije JM \& Lopez-Otin C 2012 Deubiquitinases in cancer: new functions and therapeutic options. Oncogene 31 2373-2388. (doi:10.1038/onc.2011.443)

Frankland-Searby S \& Bhaumik SR 2012 The 26 S proteasome complex: an attractive target for cancer therapy. Biochimica et Biophysica Acto 1825 64-76. (doi:10.1016/j.bbcan.2011.10.003)

Fribley A, Zeng Q \& Wang CY 2004 Proteasome inhibitor PS-341 induces apoptosis through induction of endoplasmic reticulum stress-reactive oxygen species in head and neck squamous cell carcinoma cells. Molecular and Cellular Biology 24 9695-9704. (doi:10.1128/MCB.24.22. 9695-9704.2004)

Fribley AM, Evenchik B, Zeng Q, Park BK, Guan JY, Zhang H, Hale TJ, Soengas MS, Kaufman RJ \& Wang CY 2006 Proteasome inhibitor PS-341 induces apoptosis in cisplatin-resistant squamous cell carcinoma cells by induction of Noxa. Journal of Biological Chemistry 281 31440-31447. (doi:10.1074/jbc.M604356200)

Gallastegui N \& Groll M 2010 The 26S proteasome: assembly and function of a destructive machine. Trends in Biochemical Sciences 35 634-642. (doi:10.1016/j.tibs.2010.05.005)

Gatti L, Benedetti V, De Cesare M, Corna E, Cincinelli R, Zaffaroni N, Zunino F \& Perego P 2012 Synergistic interaction between the novel histone deacetylase inhibitor ST2782 and the proteasome inhibitor bortezomib in platinum-sensitive and resistant ovarian carcinoma cells. Journal of Inorganic Biochemistry 113 94-101. (doi:10.1016/ j.jinorgbio.2012.04.007)

Ghosh S \& Baltimore D 1990 Activation in vitro of NF-кB by phosphorylation of its inhibitor IкB. Nature 344 678-682. (doi:10.1038/344678a0)

Ghosh S \& Karin M 2002 Missing pieces in the NF-кB puzzle. Cell 109 (Suppl) S81-S96. (doi:10.1016/S0092-8674(02)00703-1)

Gilbert J, Lee JW, Argiris A, Haigentz M Jr, Feldman LE, Jang M, Arun P, Van Waes C \& Forastiere AA 2013 Phase II 2-arm trial of the proteasome inhibitor, PS-341 (bortezomib) in combination with irinotecan or PS-341 alone followed by the addition of irinotecan at time of progression in patients with locally recurrent or metastatic squamous cell carcinoma of the head and neck (E1304): a trial of the Eastern Cooperative Oncology Group. Head \& Neck 35 942-948. (doi:10.1002/hed.23046)

Groll M, Ditzel L, Lowe J, Stock D, Bochtler M, Bartunik HD \& Huber R 1997 Structure of 20 S proteasome from yeast at $2.4 \AA$ resolution. Nature 386 463-471. (doi:10.1038/386463a0)

Herndon TM, Deisseroth A, Kaminskas E, Kane RC, Koti KM, Rothmann MD, Habtemariam B, Bullock J, Bray JD, Hawes J et al. 2013 U.S. Food and Drug Administration approval: carfilzomib for the treatment of multiple myeloma. Clinical Cancer Research 19 4559-4563. (doi:10.1158/1078-0432.CCR-13-0755)

Hideshima T, Richardson PG \& Anderson KC 2011 Mechanism of action of proteasome inhibitors and deacetylase inhibitors and the biological basis of synergy in multiple myeloma. Molecular Cancer Therapeutics $\mathbf{1 0}$ 2034-2042. (doi:10.1158/1535-7163.MCT-11-0433)

Hoang T, Campbell TC, Zhang C, Kim K, Kolesar JM, Oettel KR, Blank JH, Robinson EG, Ahuja HG, Kirschling RJ et al. 2013 Vorinostat and bortezomib as third-line therapy in patients with advanced non-small cell lung cancer: a Wisconsin Oncology Network Phase II study. Investigational New Drugs 32 195-199. (doi:10.1007/s10637-0139980-5)

Hui B, Shi YH, Ding ZB, Zhou J, Gu CY, Peng YF, Yang H, Liu WR, Shi GM \& Fan J 2012 Proteasome inhibitor interacts synergistically with autophagy inhibitor to suppress proliferation and induce apoptosis in hepatocellular carcinoma. Cancer 118 5560-5571. (doi:10.1002/cncr. 27586)

Irvin WJ Jr, Orlowski RZ, Chiu WK, Carey LA, Collichio FA, Bernard PS, Stijleman IJ, Perou C, Ivanova A \& Dees EC 2010 Phase II study of bortezomib and pegylated liposomal doxorubicin in the treatment of metastatic breast cancer. Clinical Breast Cancer 10 465-470. (doi:10.3816/CBC.2010.n.061)

Kale AJ \& Moore BS 2012 Molecular mechanisms of acquired proteasome inhibitor resistance. Journal of Medicinal Chemistry 55 10317-10327. (doi:10.1021/jm300434z)

Kane RC, Bross PF, Farrell AT \& Pazdur R 2003 Velcade: U.S. FDA approval for the treatment of multiple myeloma progressing on prior therapy. Oncologist 8 508-513. (doi:10.1634/theoncologist. 8-6-508) 
Kane RC, Dagher R, Farrell A, Ko CW, Sridhara R, Justice R \& Pazdur R 2007 Bortezomib for the treatment of mantle cell lymphoma. Clinical Cancer Research 13 5291-5294. (doi:10.1158/1078-0432.CCR-07-0871)

Kim J, Guan J, Chang I, Chen X, Han D \& Wang CY 2010 PS-341 and histone deacetylase inhibitor synergistically induce apoptosis in head and neck squamous cell carcinoma cells. Molecular Cancer Therapeutics 9 1977-1984. (doi:10.1158/1535-7163.MCT-10-0141)

Kim GP, Mahoney MR, Szydlo D, Mok TS, Marshke R, Holen K, Picus J, Boyer M, Pitot HC, Rubin J et al. 2012 An international, multicenter phase II trial of bortezomib in patients with hepatocellular carcinoma. Investigational New Drugs 30 387-394. (doi:10.1007/s10637-0109532-1)

Kozuch PS, Rocha-Lima CM, Dragovich T, Hochster H, O’Neil BH, Atiq OT, Pipas JM, Ryan DP \& Lenz HJ 2008 Bortezomib with or without irinotecan in relapsed or refractory colorectal cancer: results from a randomized phase II study. Journal of Clinical Oncology 26 2320-2326. (doi:10.1200/JCO.2007.14.0152)

Kraft AS, Garrett-Mayer E, Wahlquist AE, Golshayan A, Chen CS, Butler W, Bearden J \& Lilly M 2011 Combination therapy of recurrent prostate cancer with the proteasome inhibitor bortezomib plus hormone blockade. Cancer Biology \& Therapy 12 119-124. (doi:10.4161/cbt. 12.2.15723)

Kubicek GJ, Axelrod RS, Machtay M, Ahn PH, Anne PR, Fogh S, Cognetti D, Myers TJ, Curran WJ Jr \& Dicker AP 2012 Phase I trial using the proteasome inhibitor bortezomib and concurrent chemoradiotherapy for head-and-neck malignancies. International Journal of Radiation Oncology, Biology, Physics 83 1192-1197. (doi:10.1016/j.ijrobp.2011. 09.023)

Kuhn DJ, Chen Q, Voorhees PM, Strader JS, Shenk KD, Sun CM, Demo SD, Bennett MK, van Leeuwen FW, Chanan-Khan AA et al. 2007 Potent activity of carfilzomib, a novel, irreversible inhibitor of the ubiquitin-proteasome pathway, against preclinical models of multiple myeloma. Blood 110 3281-3290. (doi:10.1182/blood-2007-01065888)

Kupperman E, Lee EC, Cao Y, Bannerman B, Fitzgerald M, Berger A, Yu J, Yang Y, Hales P, Bruzzese F et al. 2010 Evaluation of the proteasome inhibitor MLN9708 in preclinical models of human cancer. Cancer Research 70 1970-1980. (doi:10.1158/0008-5472.CAN-09-2766)

Lara PN Jr, Longmate J, Reckamp K, Gitlitz B, Argiris A, Ramalingam S, Belani CP, Mack PC, Lau DH, Koczywas M et al. 2011 Randomized phase II trial of concurrent versus sequential bortezomib plus docetaxel in advanced non-small-cell lung cancer: a California cancer consortium trial. Clinical Lung Cancer 12 33-37. (doi:10.3816/CLC. 2011.n.004)

Li C \& Johnson DE 2012 Bortezomib induces autophagy in head and neck squamous cell carcinoma cells via JNK activation. Cancer Letters $\mathbf{3 1 4}$ 102-107. (doi:10.1016/j.canlet.2011.09.020)

Li C, Li R, Grandis JR \& Johnson DE 2008 Bortezomib induces apoptosis via Bim and Bik up-regulation and synergizes with cisplatin in the killing of head and neck squamous cell carcinoma cells. Molecular Cancer Therapeutics 7 1647-1655. (doi:10.1158/1535-7163.MCT07-2444)

Li C, Zang Y, Sen M, Leeman-Neill RJ, Man DS, Grandis JR \& Johnson DE 2009 Bortezomib up-regulates activated signal transducer and activator of transcription-3 and synergizes with inhibitors of signal transducer and activator of transcription-3 to promote head and neck squamous cell carcinoma cell death. Molecular Cancer Therapeutics 8 2211-2220. (doi:10.1158/1535-7163.MCT-09-0327)

Li T, Ho L, Piperdi B, Elrafei T, Camacho FJ, Rigas JR, Perez-Soler R \& Gucalp R 2010 Phase II study of the proteasome inhibitor bortezomib (PS-341, Velcade) in chemotherapy-naive patients with advanced stage non-small cell lung cancer (NSCLC). Lung Cancer 68 89-93. (doi:10.1016/j.lungcan.2009.05.009)

Lin Z, Bazzaro M, Wang MC, Chan KC, Peng S \& Roden RB 2009 Combination of proteasome and HDAC inhibitors for uterine cervical cancer treatment. Clinical Cancer Research 15 570-577. (doi:10.1158/ 1078-0432.CCR-08-1813)

Linenberger ML, Hong T, Flowers D, Sievers EL, Gooley TA, Bennett JM Berger MS, Leopold LH, Appelbaum FR \& Bernstein ID 2001 Multidrug-resistance phenotype and clinical responses to gemtuzumab ozogamicin. Blood 98 988-994. (doi:10.1182/blood.V98.4.988)

Liu X, Yue P, Chen S, Hu L, Lonial S, Khuri FR \& Sun SY 2007 The proteasome inhibitor PS-341 (bortezomib) up-regulates DR5 expression leading to induction of apoptosis and enhancement of TRAIL-induced apoptosis despite up-regulation of c-FLIP and survivin expression in human NSCLC cells. Cancer Research 67 4981-4988. (doi:10.1158/ 0008-5472.CAN-06-4274)

Liu S, Liu Z, Xie Z, Pang J, Yu J, Lehmann E, Huynh L, Vukosavljevic T, Takeki M, Klisovic RB et al. 2008 Bortezomib induces DNA hypomethylation and silenced gene transcription by interfering with Sp1/NF- $\kappa$ B-dependent DNA methyltransferase activity in acute myeloid leukemia. Blood 111 2364-2373. (doi:10.1182/blood-200708-110171)

Lonial S, Waller EK, Richardson PG, Jagannath S, Orlowski RZ, Giver CR, Jaye DL, Francis D, Giusti S, Torre C et al. 2005 Risk factors and kinetics of thrombocytopenia associated with bortezomib for relapsed, refractory multiple myeloma. Blood 106 3777-3784. (doi:10.1182/blood2005-03-1173)

Macherla VR, Mitchell SS, Manam RR, Reed KA, Chao TH, Nicholson B, Deyanat-Yazdi G, Mai B, Jensen PR, Fenical WF et al. 2005 Structureactivity relationship studies of salinosporamide A (NPI-0052), a novel marine derived proteasome inhibitor. Journal of Medicinal Chemistry 48 3684-3687. (doi:10.1021/jm048995+)

Mackay H, Hedley D, Major P, Townsley C, Mackenzie M, Vincent M, Degendorfer P, Tsao MS, Nicklee T, Birle D et al. 2005 A phase II trial with pharmacodynamic endpoints of the proteasome inhibitor bortezomib in patients with metastatic colorectal cancer. Clinical Cancer Research 11 5526-5533. (doi:10.1158/1078-0432. CCR-05-0081)

Markovic SN, Geyer SM, Dawkins F, Sharfman W, Albertini M, Maples W, Fracasso PM, Fitch T, Lorusso P, Adjei AA et al. 2005 A phase II study of bortezomib in the treatment of metastatic malignant melanoma. Cancer 103 2584-2589. (doi:10.1002/cncr.21108)

Merlet J, Burger J, Gomes JE \& Pintard L 2009 Regulation of cullin-RING E3 ubiquitin-ligases by neddylation and dimerization. Cellular and Molecular Life Sciences 66 1924-1938. (doi:10.1007/s00018-009-8712-7)

Milhollen MA, Narayanan U, Soucy TA, Veiby PO, Smith PG \& Amidon B 2011 Inhibition of NEDD8-activating enzyme induces rereplication and apoptosis in human tumor cells consistent with deregulating CDT1 turnover. Cancer Research 71 3042-3051. (doi:10.1158/0008-5472. CAN-10-2122)

Miller CP, Ban K, Dujka ME, McConkey DJ, Munsell M, Palladino M \& Chandra J 2007 NPI-0052, a novel proteasome inhibitor, induces caspase- 8 and ROS-dependent apoptosis alone and in combination with HDAC inhibitors in leukemia cells. Blood 110 267-277. (doi:10.1182/blood-2006-03-013128)

Miyashita T \& Reed JC 1995 Tumor suppressor p53 is a direct transcriptional activator of the human bax gene. Cell 80 293-299. (doi:10.1016/0092-8674(95)90513-8)

Morris MJ, Kelly WK, Slovin S, Ryan C, Eicher C, Heller G \& Scher HI 2007 A phase II trial of bortezomib and prednisone for castration resistant metastatic prostate cancer. Journal of Urology 178 2378-2383 (discussion 2383-2384). (doi:10.1016/j.juro.2007.08.015)

Nasman A, Attner P, Hammarstedt L, Du J, Eriksson M, Giraud G, Ahrlund-Richter S, Marklund L, Romanitan M, Lindquist D et al. 2009 Incidence of human papillomavirus (HPV) positive tonsillar carcinoma in Stockholm, Sweden: an epidemic of viral-induced carcinoma? International Journal of Cancer 125 362-366. (doi:10.1002/ ijc.24339)

Nawrocki ST, Bruns CJ, Harbison MT, Bold RJ, Gotsch BS, Abbruzzese JL, Elliott P, Adams J \& McConkey DJ 2002 Effects of the proteasome 
inhibitor PS-341 on apoptosis and angiogenesis in orthotopic human pancreatic tumor xenografts. Molecular Cancer Therapeutics $\mathbf{1}$ 1243-1253

Nikrad M, Johnson T, Puthalalath H, Coultas L, Adams J \& Kraft AS 2005 The proteasome inhibitor bortezomib sensitizes cells to killing by death receptor ligand TRAIL via BH3-only proteins Bik and Bim. Molecular Cancer Therapeutics 4 443-449.

O'Connor OA, Wright J, Moskowitz C, Muzzy J, MacGregor-Cortelli B, Stubblefield M, Straus D, Portlock C, Hamlin P, Choi E et al. 2005 Phase II clinical experience with the novel proteasome inhibitor bortezomib in patients with indolent non-Hodgkin's lymphoma and mantle cell lymphoma. Journal of Clinical Oncology 23 676-684. (doi:10.1200/JCO.2005.02.050)

O'Connor OA, Stewart AK, Vallone M, Molineaux CJ, Kunkel LA, Gerecitano JF \& Orlowski RZ 2009 A phase 1 dose escalation study of the safety and pharmacokinetics of the novel proteasome inhibitor carfilzomib (PR-171) in patients with hematologic malignancies. Clinical Cancer Research 15 7085-7091. (doi:10.1158/1078-0432. CCR-09-0822)

Oda E, Ohki R, Murasawa H, Nemoto J, Shibue T, Yamashita T, Tokino T, Taniguchi T \& Tanaka N 2000 Noxa, a BH3-only member of the Bcl-2 family and candidate mediator of p53-induced apoptosis. Science $\mathbf{2 8 8}$ 1053-1058. (doi:10.1126/science.288.5468.1053)

Opferman JT 2006 Unraveling MCL-1 degradation. Cell Death and Differentiation 13 1260-1262. (doi:10.1038/sj.cdd.4401978)

Orlowski M \& Wilk S 2000 Catalytic activities of the 20 S proteasome, a multicatalytic proteinase complex. Archives of Biochemistry and Biophysics 383 1-16. (doi:10.1006/abbi.2000.2036)

Orlowski RZ, Nagler A, Sonneveld P, Blade J, Hajek R, Spencer A, San Miguel J, Robak T, Dmoszynska A, Horvath N et al. 2007 Randomized phase III study of pegylated liposomal doxorubicin plus bortezomib compared with bortezomib alone in relapsed or refractory multiple myeloma: combination therapy improves time to progression. Journal of Clinical Oncology 25 3892-3901. (doi:10.1200/JCO.2006. 10.5460)

Parma G, Mancari R, Del Conte G, Scambia G, Gadducci A, Hess D, Katsaros D, Sessa C, Rinaldi A, Bertoni F et al. 2012 An open-label phase 2 study of twice-weekly bortezomib and intermittent pegylated liposomal doxorubicin in patients with ovarian cancer failing platinum-containing regimens. International Journal of Gynecological Cancer 22 792-800. (doi:10.1097/IGC.0b013e318251051a)

Pei XY, Dai Y \& Grant S 2004 Synergistic induction of oxidative injury and apoptosis in human multiple myeloma cells by the proteasome inhibitor bortezomib and histone deacetylase inhibitors. Clinical Cancer Research 10 3839-3852. (doi:10.1158/1078-0432.CCR03-0561)

Perez-Galan P, Roue G, Villamor N, Campo E \& Colomer D 2007 The BH3-mimetic GX15-070 synergizes with bortezomib in mantle cell lymphoma by enhancing Noxa-mediated activation of Bak. Blood 109 4441-4449. (doi:10.1182/blood-2006-07-034173)

Perez-Galan P, Roue G, Lopez-Guerra M, Nguyen M, Villamor N, Montserrat E, Shore GC, Campo E \& Colomer D 2008 BCL-2 phosphorylation modulates sensitivity to the BH3 mimetic GX15-070 (Obatoclax) and reduces its synergistic interaction with bortezomib in chronic lymphocytic leukemia cells. Leukemia 22 1712-1720. (doi:10.1038/leu.2008.175)

Petrocca F, Altschuler G, Tan SM, Mendillo ML, Yan H, Jerry DJ, Kung AL, Hide W, Ince TA \& Lieberman J 2013 A genome-wide siRNA screen identifies proteasome addiction as a vulnerability of basal-like triplenegative breast cancer cells. Cancer Cell 24 182-196. (doi:10.1016/j.ccr. 2013.07.008)

Piperdi B, Walsh WV, Bradley K, Zhou Z, Bathini V, Hanrahan-Boshes M, Hutchinson L \& Perez-Soler R 2012 Phase-I/II study of bortezomib in combination with carboplatin and bevacizumab as first-line therapy in patients with advanced non-small-cell lung cancer. Journal of Thoracic Oncology 7 1032-1040. (doi:10.1097/JTO.0b013e31824de2fa)
Pitts TM, Morrow M, Kaufman SA, Tentler JJ \& Eckhardt SG 2009 Vorinostat and bortezomib exert synergistic antiproliferative and proapoptotic effects in colon cancer cell models. Molecular Cancer Therapeutics 8 342-349. (doi:10.1158/1535-7163.MCT-08-0534)

Piva R, Ruggeri B, Williams M, Costa G, Tamagno I, Ferrero D, Giai V, Coscia M, Peola S, Massaia M et al. 2008 CEP-18770: a novel, orally active proteasome inhibitor with a tumor-selective pharmacologic profile competitive with bortezomib. Blood 111 2765-2775. (doi:10.1182/blood-2007-07-100651)

Poeta ML, Manola J, Goldwasser MA, Forastiere A, Benoit N, Califano JA, Ridge JA, Goodwin J, Kenady D, Saunders J et al. 2007 TP53 mutations and survival in squamous-cell carcinoma of the head and neck. New England Journal of Medicine 357 2552-2561. (doi:10.1056/ NEJMoa073770)

Popat R, Oakervee H, Williams C, Cook M, Craddock C, Basu S, Singer C, Harding S, Foot N, Hallam S et al. 2009 Bortezomib, low-dose intravenous melphalan, and dexamethasone for patients with relapsed multiple myeloma. British Journal of Haematology 144 887-894. (doi:10.1111/j.1365-2141.2008.07572.x)

Pugh TJ, Chen C, Rabinovitch R, Eckhardt SG, Rusthoven KE, Swing R \& Raben D 2010 Phase I trial of bortezomib and concurrent external beam radiation in patients with advanced solid malignancies. International Journal of Radiation Oncology, Biology, Physics 78 521-526. (doi:10.1016/ j.ijrobp.2009.07.1715)

Qin JZ, Ziffra J, Stennett L, Bodner B, Bonish BK, Chaturvedi V, Bennett F, Pollock PM, Trent JM, Hendrix MJ et al. 2005 Proteasome inhibitors trigger NOXA-mediated apoptosis in melanoma and myeloma cells. Cancer Research 65 6282-6293. (doi:10.1158/0008-5472.CAN-05-0676)

Ramalingam SS, Davies AM, Longmate J, Edelman MJ, Lara PN Jr, Vokes EE, Villalona-Calero M, Gitlitz B, Reckamp K, Salgia R et al. 2011 Bortezomib for patients with advanced-stage bronchioloalveolar carcinoma: a California Cancer Consortium Phase II study (NCI 7003). Journal of Thoracic Oncology 6 1741-1745. (doi:10.1097/JTO. Ob013e318225924c)

Reece DE, Rodriguez GP, Chen C, Trudel S, Kukreti V, Mikhael J, Pantoja M, Xu W \& Stewart AK 2008 Phase I-II trial of bortezomib plus oral cyclophosphamide and prednisone in relapsed and refractory multiple myeloma. Journal of Clinical Oncology 26 4777-4783. (doi:10.1200/JCO. 2007.14.2372)

Richardson PG, Barlogie B, Berenson J, Singhal S, Jagannath S, Irwin D, Rajkumar SV, Srkalovic G, Alsina M, Alexanian R et al. 2003 A phase 2 study of bortezomib in relapsed, refractory myeloma. New England Journal of Medicine 348 2609-2617. (doi:10.1056/NEJMoa030288)

Richardson PG, Sonneveld P, Schuster MW, Irwin D, Stadtmauer EA, Facon T, Harousseau JL, Ben-Yehuda D, Lonial S, Goldschmidt H et al. 2005 Bortezomib or high-dose dexamethasone for relapsed multiple myeloma. New England Journal of Medicine 352 2487-2498. (doi:10. 1056/NEJMoa043445)

Richardson PG, Briemberg H, Jagannath S, Wen PY, Barlogie B, Berenson J, Singhal S, Siegel DS, Irwin D, Schuster M et al. 2006 Frequency, characteristics, and reversibility of peripheral neuropathy during treatment of advanced multiple myeloma with bortezomib. Journal of Clinical Oncology 24 3113-3120. (doi:10.1200/JCO.2005.04.7779)

Richardson PG, Schlossman RL, Alsina M, Weber DM, Coutre SE, Gasparetto C, Mukhopadhyay S, Ondovik MS, Khan M, Paley CS et al. 2013 PANORAMA 2: panobinostat in combination with bortezomib and dexamethasone in patients with relapsed and bortezomibrefractory myeloma. Blood 122 2331-2337. (doi:10.1182/blood-201301-481325)

Saha MN, Qiu L \& Chang H 2013 Targeting p53 by small molecules in hematological malignancies. Journal of Hematology \& Oncology 623. (doi:10.1186/1756-8722-6-23)

Scheffner M, Huibregtse JM, Vierstra RD \& Howley PM 1993 The HPV-16 E6 and E6-AP complex functions as a ubiquitin-protein ligase in the ubiquitination of p53. Cell 75 495-505. (doi:10.1016/0092-8674 (93)90384-3) 
Seki N, Toh U, Sayers TJ, Fujii T, Miyagi M, Akagi Y, Kusukawa J, Kage M, Shirouzu K \& Yamana H 2010 Bortezomib sensitizes human esophageal squamous cell carcinoma cells to TRAIL-mediated apoptosis via activation of both extrinsic and intrinsic apoptosis pathways. Molecular Cancer Therapeutics 9 1842-1851. (doi:10.1158/1535-7163.MCT-090918)

Shah MA, Power DG, Kindler HL, Holen KD, Kemeny MM, Ilson DH, Tang L, Capanu M, Wright JJ \& Kelsen DP 2011 A multicenter, phase II study of bortezomib (PS-341) in patients with unresectable or metastatic gastric and gastroesophageal junction adenocarcinoma. Investigational New Drugs 29 1475-1481. (doi:10.1007/s10637010-9474-7)

Shanker A, Brooks AD, Tristan CA, Wine JW, Elliott PJ, Yagita H, Takeda K, Smyth MJ, Murphy WJ \& Sayers TJ 2008 Treating metastatic solid tumors with bortezomib and a tumor necrosis factor-related apoptosisinducing ligand receptor agonist antibody. Journal of the National Cancer Institute 100 649-662. (doi:10.1093/jnci/djn113)

Shen M, Schmitt S, Buac D \& Dou QP 2013 Targeting the ubiquitinproteasome system for cancer therapy. Expert Opinion on Therapeutic Targets 17 1091-1108. (doi:10.1517/14728222.2013.815728)

Shiboski CH, Schmidt BL \& Jordan RC 2005 Tongue and tonsil carcinoma: increasing trends in the U.S. population ages 20-44 years. Cancer 103 1843-1849. (doi:10.1002/cncr.20998)

Siegel D, Martin T, Nooka A, Harvey RD, Vij R, Niesvizky R, Badros AZ, Jagannath S, McCulloch L, Rajangam K et al. 2013 Integrated safety profile of single-agent carfilzomib: experience from 526 patients enrolled in 4 phase 2 clinical studies. Haematologia 98 1753-1761. (doi:10.3324/haematol.2013.089334)

Soucy TA, Smith PG, Milhollen MA, Berger AJ, Gavin JM, Adhikari S, Brownell JE, Burke KE, Cardin DP, Critchley S et al. 2009 An inhibitor of NEDD8-activating enzyme as a new approach to treat cancer. Nature 458 732-736. (doi:10.1038/nature07884)

Soucy TA, Dick LR, Smith PG, Milhollen MA \& Brownell JE 2010 The NEDD8 conjugation pathway and its relevance in cancer biology and therapy. Genes \& Cancer 1 708-716. (doi:10.1177/1947601910 382898)

Spratlin JL, Pitts TM, Kulikowski GN, Morelli MP, Tentler JJ, Serkova NJ \& Eckhardt SG 2011 Synergistic activity of histone deacetylase and proteasome inhibition against pancreatic and hepatocellular cancer cell lines. Anticancer Research 31 1093-1103.

Sunwoo JB, Chen Z, Dong G, Yeh N, Crowl Bancroft C, Sausville E, Adams J, Elliott P \& Van Waes C 2001 Novel proteasome inhibitor PS-341 inhibits activation of nuclear factor- $\mathrm{\kappa B}$, cell survival, tumor growth, and angiogenesis in squamous cell carcinoma. Clinical Cancer Research 7 1419-1428.

Terpos E, Kastritis E, Roussou M, Heath D, Christoulas D, Anagnostopoulos N, Eleftherakis-Papaiakovou E, Tsionos K, Croucher P \& Dimopoulos MA 2008 The combination of bortezomib, melphalan, dexamethasone and intermittent thalidomide is an effective regimen for relapsed/refractory myeloma and is associated with improvement of abnormal bone metabolism and angiogenesis. Leukemia 22 2247-2256. (doi:10.1038/ leu.2008.235)

Tian Z, D'Arcy P, Wang X, Ray A, Tai YT, Hu Y, Carrasco RD, Richardson P, Linder S, Chauhan D et al. 2014 A novel small molecule inhibitor of deubiquitylating enzyme USP14 and UCHL5 induces apoptosis in multiple myeloma and overcomes bortezomib resistance. Blood $\mathbf{1 2 3}$ 706-716. (doi:10.1182/blood-2013-05-500033)

Traenckner EB, Wilk S \& Baeuerle PA 1994 A proteasome inhibitor prevents activation of NF- $\mathrm{BB}$ and stabilizes a newly phosphorylated

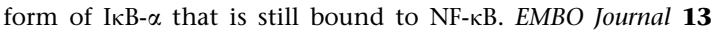
5433-5441.

Traenckner EB, Pahl HL, Henkel T, Schmidt KN, Wilk S \& Baeuerle PA 1995

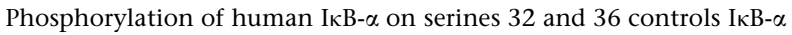
proteolysis and NF- $\kappa \mathrm{B}$ activation in response to diverse stimuli. EMBO Journal 14 2876-2883.
Van Waes C 2007 Nuclear factor-кB in development, prevention, and therapy of cancer. Clinical Cancer Research 13 1076-1082. (doi:10.1158/ 1078-0432.CCR-06-2221)

Van Waes C, Chang AA, Lebowitz PF, Druzgal CH, Chen Z, Elsayed YA, Sunwoo JB, Rudy SF, Morris JC, Mitchell JB et al. 2005 Inhibition of nuclear factor- $\mathrm{kB}$ and target genes during combined therapy with proteasome inhibitor bortezomib and reirradiation in patients with recurrent head-and-neck squamous cell carcinoma. International Journal of Radiation Oncology, Biology, Physics 63 1400-1412. (doi:10.1016/j.ijrobp.2005.05.007)

Vassilev LT 2007 MDM2 inhibitors for cancer therapy. Trends in Molecular Medicine 13 23-31. (doi:10.1016/j.molmed.2006.11.002)

Vassilev LT, Vu BT, Graves B, Carvajal D, Podlaski F, Filipovic Z, Kong N, Kammlott U, Lukacs C, Klein C et al. 2004 In vivo activation of the p53 pathway by small-molecule antagonists of MDM2. Science $\mathbf{3 0 3}$ 844-848. (doi:10.1126/science.1092472)

Verbrugge SE, Assaraf YG, Dijkmans BA, Scheffer GL, Al M, den Uyl D, Oerlemans R, Chan ET, Kirk CJ, Peters GJ et al. 2012 Inactivating PSMB5 mutations and P-glycoprotein (multidrug resistance-associated protein/ATP-binding cassette B1) mediate resistance to proteasome inhibitors: ex vivo efficacy of (immuno)proteasome inhibitors in mononuclear blood cells from patients with rheumatoid arthritis. Journal of Pharmacological and Experimental Therapeutics 341 174-182. (doi:10.1124/jpet.111.187542)

Voortman J, Checinska A, Giaccone G, Rodriguez JA \& Kruyt FA 2007a Bortezomib, but not cisplatin, induces mitochondria-dependent apoptosis accompanied by up-regulation of noxa in the non-small cell lung cancer cell line NCI-H460. Molecular Cancer Therapeutics 6 1046-1053. (doi:10.1158/1535-7163.MCT-06-0577)

Voortman J, Resende TP, Abou El Hassan MA, Giaccone G \& Kruyt FA 2007b TRAIL therapy in non-small cell lung cancer cells: sensitization to death receptor-mediated apoptosis by proteasome inhibitor bortezomib. Molecular Cancer Therapeutics 6 2103-2112. (doi:10.1158/1535-7163. MCT-07-0167)

Westra WH, Taube JM, Poeta ML, Begum S, Sidransky D \& Koch WM 2008 Inverse relationship between human papillomavirus-16 infection and disruptive p53 gene mutations in squamous cell carcinoma of the head and neck. Clinical Cancer Research 14 366-369. (doi:10.1158/10780432.CCR-07-1402)

Williams S, Pettaway C, Song R, Papandreou C, Logothetis C \& McConkey DJ 2003 Differential effects of the proteasome inhibitor bortezomib on apoptosis and angiogenesis in human prostate tumor xenografts. Molecular Cancer Therapeutics 2 835-843.

Yang H, Zonder JA \& Dou QP 2009 Clinical development of novel proteasome inhibitors for cancer treatment. Expert Opinion on Investigational Drugs 18 957-971. (doi:10.1517/13543780903002074)

Yoshiba S, Iwase M, Kurihara S, Uchida M, Kurihara Y, Watanabe H \& Shintani S 2011 Proteasome inhibitor sensitizes oral squamous cell carcinoma cells to TRAIL-mediated apoptosis. Oncology Reports $\mathbf{2 5}$ 645-652. (doi:10.3892/or.2010.1127)

Yu C, Rahmani M, Conrad D, Subler M, Dent P \& Grant S 2003 The proteasome inhibitor bortezomib interacts synergistically with histone deacetylase inhibitors to induce apoptosis in $\mathrm{Bcr} / \mathrm{Abl}+$ cells sensitive and resistant to STI571. Blood 102 3765-3774. (doi:10.1182/blood2003-03-0737)

Zang Y, Thomas SM, Chan ET, Kirk CJ, Freilino ML, DeLancey HM, Grandis JR, Li C \& Johnson DE 2012a Carfilzomib ONX 0912 inhibit cell survival and tumor growth of head and neck cancer and their activities are enhanced by suppression of Mcl-1 or autophagy. Clinical Cancer Research 18 5639-5649. (doi:10.1158/1078-0432. CCR-12-1213)

Zang Y, Thomas SM, Chan ET, Kirk CJ, Freilino ML, DeLancey HM, Grandis JR, Li C \& Johnson DE $2012 b$ The next generation proteasome inhibitors carfilzomib and oprozomib activate prosurvival autophagy via induction of the unfolded protein response and ATF4. Autophagy 8 1873-1874. (doi:10.4161/auto.22185)

Published by Bioscientifica Ltd 
Zhou HJ, Aujay MA, Bennett MK, Dajee M, Demo SD, Fang Y, Ho MN, Jiang J, Kirk CJ, Laidig GJ et al. 2009 Design and synthesis of an orally bioavailable and selective peptide epoxyketone proteasome inhibitor (PR-047). Journal of Medicinal Chemistry 52 3028-3038. (doi:10.1021/ jm801329v)

Zhu H, Guo W, Zhang L, Wu S, Teraishi F, Davis JJ, Dong F \& Fang B 2005a Proteasome inhibitors-mediated TRAIL resensitization and Bik accumulation. Cancer Biology \& Therapy 4 781-786. (doi:10.4161/cbt.4.7.1897)
Zhu H, Zhang L, Dong F, Guo W, Wu S, Teraishi F, Davis JJ, Chiao PJ \& Fang B 2005 b Bik/NBK accumulation correlates with apoptosisinduction by bortezomib (PS-341, Velcade) and other proteasome inhibitors. Oncogene 24 4993-4999. (doi:10.1038/sj.onc. 1208683)

Zhu K, Dunner K Jr \& McConkey DJ 2009 Proteasome inhibitors activate autophagy as a cytoprotective response in human prostate cancer cells. Oncogene 29 451-462. (doi:10.1038/onc.2009.343)

Received in final form 18 March 2014

Accepted 21 March 2014

Made available online as an Accepted Preprint

21 March 2014
Published by Bioscientifica Ltd. 